\title{
Technical assessment of the Biomass Integrated Gasification/Gas Turbine Combined Cycle (BIG/GTCC) incorporation in the sugarcane industry
}

\author{
Daniel Travieso Pedroso, Einara Blanco Machin*, Nestor Proenza Pérez**, \\ Lúcia Bollini Braga, José Luz Silveira
}

São Paulo State University, Faculty of Engineering of Guaratinguetá, Energy Department, Brazil

\section{A R T I C L E I N F O}

\section{Article history:}

Received 20 July 2015

Received in revised form

27 January 2017

Accepted 10 July 2017

Available online 14 July 2017

\section{Keywords:}

Sugar cane bagasse gasification

Entrained flow gasifier

Bagasse torrefaction

Electricity generation

\begin{abstract}
A B S T R A C T
Biomass Integrated Gasifier/Gas Turbine Combined Cycle (BIG/GTCC) systems in the sugarcane industry, are capable to produce more electricity per unit of biomass consumed than the conventional Condensing Extraction Steam Turbine (CEST) systems. A technical analysis of the introduction of BIG/GTCC technology in the sugarcane industry for electricity and heat generation, using wet sugarcane bagasse as fuel, was conducted. For sugar plants, with large steam requirements, the implementation of the "pure" BIG/ GTCC is not convenient due to the size of the required gas turbine and of the gasification island. The "partial" BIG/GTCC appear to be better alternative, by the combination of the torrefaction pretreatment and entrained flow gasifier, CHOREN Carbo- $V^{\circledR}$ type, permitting a net electricity generation efficiency of $14.7 \%$ and the increment of the CEST cogeneration efficiency; , using wet sugarcane bagasse as feedstock. This arrangement avoid observed problems in previous experiences with the continuum handling and feeding of shredded sugarcane bagasse to the gasifier.
\end{abstract}

๑) 2017 Elsevier Ltd. All rights reserved.

\section{Introduction}

Sugar cane is cultivated in more than 80 countries and the byproducts obtained from the sugar production process represent a great biomass potential. The harvest of sugarcane in the producing countries is about $1.2 \mathrm{Gt}$ and potentially its residue can be used for an electric power production of about $300 \mathrm{TWh} \mathrm{y}^{-1}$ [1]. Sugar cane has a great capacity to produce biomass, yielding about $100 \mathrm{tha}^{-1}$.

Traditionally, sugar mills use bagasse with high moisture content and cane trash as fuel for low-pressure boilers to generate steam for power generation using a conventional condensingextraction steam-turbine (CEST) technology, to provide the plant of heat, electricity and mechanical power.

The Biomass Integrated-Gasifier/Gas Turbine Combined Cycle (BIG/GTCC) technology, has being identified by several authors [2-5] as an advanced technology; with the potential to be costcompetitive with CEST in the sugar industry; increasing the electricity generated per unit of sugarcane processed.

Larson et al. [2] reviews the BIG/GTCC designs and commercial projects and presented estimates of the performance of two different BIG/GTCC plant configurations integrated into sugar mills (total and partial integration). In the study were not considered unsolved the problems observed during the continue feed of gasifier with sugarcane bagasse. The gasifier types considered was fluidized-bed reactors.

On this background, the objective of this work is to perform a study of the introduction viability of the BIG/GTCC technology in the sugar industry in order to increase the electricity generation from renewable energy sources of energy, in a sustainably way. The study will analyzes two possible configurations for the incorporation of this technology, considering the use of an advanced gasification technology (entrained flow) and the inclusion of torrefaction pretreatment technology to overcome the feeding problems observed when sugarcane bagasse is feed continuously to a gasifier $[1,2]$.

\footnotetext{
* Corresponding author.

** Corresponding author. Federal Center of Technological Education Celso Suckow

da Fonseca (CEFET/RJ), Campus Angra dos Reis, RJ, Brazil.

E-mail address: einara@feg.unesp.br (E.B. Machin).
} 


\begin{tabular}{|c|c|c|c|}
\hline \multicolumn{2}{|c|}{ Nomenclature } & \multirow{3}{*}{$\begin{array}{l}\eta_{G E} \\
\eta_{G L} \\
\eta_{e}\end{array}$} & \multirow{3}{*}{$\begin{array}{l}\text { Electricity generation efficiency [\%] } \\
\text { Global efficiency [\%] } \\
\text { Efficiency of gas turbine electricity generator [\%] }\end{array}$} \\
\hline$\dot{m}_{x}$ & Mass flux of element $x[\mathrm{~kg} / \mathrm{s}]$ & & \\
\hline$\Delta h_{x}$ & Fnthalny change of the element y [MU/ko] & & \\
\hline & Entnalpy change or the element $x$ [IV]/Kg] & $\eta_{\text {gasifier }}$ & Reactor cold gas efficiency [\%] \\
\hline$n_{f g}$ & Water vaporization enthalpy [MJ/kg] & $\eta_{\text {tgiso }}$ & Isentropic efficiency of the compressor [\%] \\
\hline $\mathrm{Q}_{T}$ & Heat lost in the torrefaction reactor [MW] & BFBG & Bubbling Fluidized Bed Gasifier \\
\hline$E_{\text {comb }}$ & Energy supplied by the sugarcane bagasse [MW] & EFG & Entrained Flow Gasifier \\
\hline$E_{\text {tge }}$ & Electricity generate by the gas turbine [MW] & HRSG & Heat Recovery Steam Generator \\
\hline$E_{t v e}$ & Electricity generate by the steam turbine [MW] & $\mathrm{HHW}_{\mathrm{x}}$ & Higher heating value of element $\mathrm{x}[\mathrm{MJ} / \mathrm{kg}]$ \\
\hline$Q_{G}$ & Heat lost in the gasifier reactor [MW] & $L H W_{x}$ & Lower heating value of element $\mathrm{x}[\mathrm{MJ} / \mathrm{kg}]$ \\
\hline$Q_{\text {Proc }}$ & $\begin{array}{l}\text { Thermal energy of consumed by the sugar production } \\
\text { process }[\mathrm{kW}]\end{array}$ & $C p$ & Specific heat at constant pressure $[1 / \mathrm{kg} \mathrm{K}]$ \\
\hline$Q_{e g}$ & Thermal energy of exhaust gases $[\mathrm{kW}]$ & Subscripts & \\
\hline$Q_{s}$ & Heat lost in the dryer [MW] & bgTorref & Torrefied sugarcane bagasse \\
\hline \multirow[t]{2}{*}{$W_{C A S U}$} & Energy consumed by the Cryogenic Air Separation Unit & $\mathrm{CC}$ & Combustion chamber \\
\hline & {$[\mathrm{MW}]$} & GE & Exhaust gases \\
\hline \multirow[t]{2}{*}{$W_{L H V}$} & Energy consumed by the producer gas compressor & GEC & Exhaust gases of bagasse combustor \\
\hline & {$[\mathrm{MW}]$} & GET & Exhaust gases of HRSG \\
\hline \multirow[t]{2}{*}{$W_{M e c}$} & Mechanical energy consumed by the sugar production & Pgas & producer gas) \\
\hline & process & $d b g$ & Dried bagasse \\
\hline$W_{\text {Mill }}$ & Energy consumed by the torrefied bagasse mill [MW] & $w b g$ & Wet bagasse \\
\hline$W_{b}$ & Energy consumed by the HRSG pump [MW] & & \\
\hline
\end{tabular}

\section{The conventional condensing-extraction steam-turbine technology}

A conventional condensing-extraction steam-turbine (CEST) technology is traditionally used by the sugarcane industry using bagasse as fuel to generate the plants' energy requirements. In a simple Rankine cycle (Fig. 1), high pressure superheated steam is used as the working fluid, generated from saturated liquid water (feed-water). This saturated steam flows through the turbine, where its internal energy is converted into mechanical work to run an electricity generation system. Not all the energy from steam can be utilized for running the generating system because of losses due to friction, viscosity, bend-on-blade etc. and most of the heat energy is rejected in the steam condenser. The feed water brings the

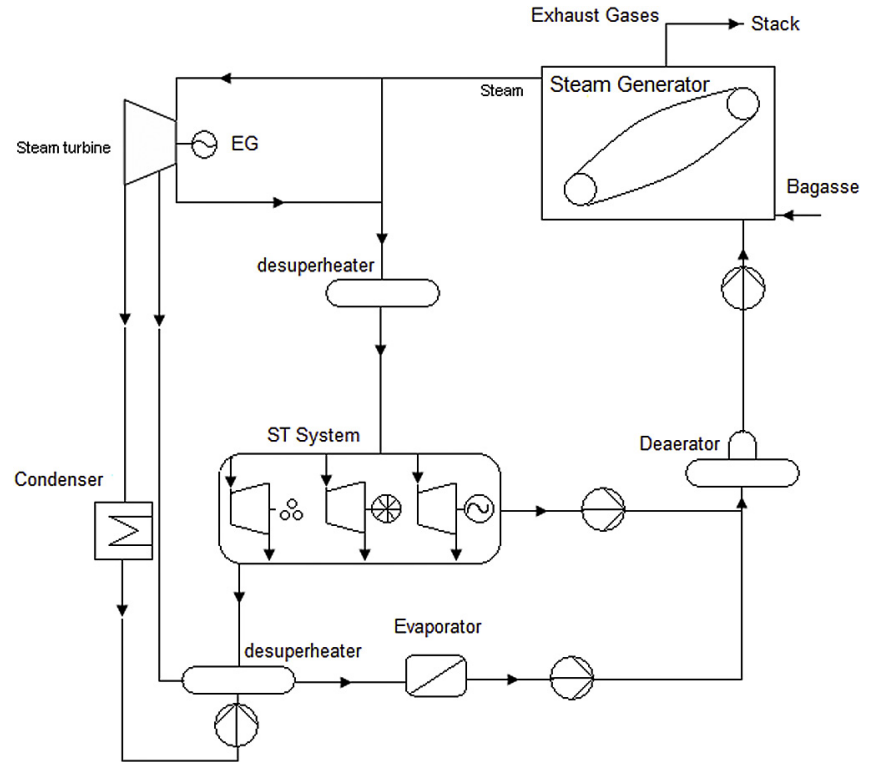

Fig. 1. CEST configuration. condensed water back to the steam generator.

In recent years more modern systems for burning bagasse in suspension have been introduced, that allow to raise the steam pressure and temperature for the purpose of obtaining a higher electric power cycle cogeneration [6]. According to Barroso et al. [7], the typical overall efficiency of this process is in the $15-30 \%$ range, consequently the size of conventional combined heat and power generation plants from bagasse, have been limited by these low efficiencies and the amount of fuel within an economical transportation radius.

\section{Biomass gasification}

Gasification is the key technology of biomass based power generation. Is a high-temperature process (873-1273 K) that decomposes complex biomass hydrocarbons into gaseous molecules, primarily hydrogen, carbon monoxide, and carbon dioxide; also are formed some tars (PAH- polycyclic aromatic hydrocarbon), char, methane, water, and other constituents [8-11]. Hydrogen and carbon monoxide are the desired product gases, because they can fed directly gas turbines for power generation or used in chemical synthesis. The main reactions of biomass gasification are as follows:

$$
\begin{aligned}
& \mathrm{C}+\mathrm{H}_{2} \mathrm{O} \rightarrow \mathrm{CO}+\mathrm{H}_{2} \quad \Delta H_{298}^{0}=131.5 \mathrm{~kJ} \mathrm{~mol}^{-1} \\
& \mathrm{C}+\mathrm{CO}_{2} \rightarrow 2 \mathrm{CO} \quad \Delta H_{298}^{0}=172 \mathrm{~kJ} \mathrm{~mol}^{-1} \\
& \mathrm{CO}+\mathrm{H}_{2} \mathrm{O} \rightarrow \mathrm{CO}_{2}+\mathrm{H}_{2} \quad \Delta \mathrm{H}_{298}^{0}=41 \mathrm{~kJ} \mathrm{~mol}^{-1} \\
& \mathrm{CH}_{4}+\mathrm{H}_{2} \mathrm{O} \rightarrow \mathrm{CO}+3 \mathrm{H}_{2} \quad \Delta \mathrm{H}_{298}^{0}=206 \mathrm{~kJ} \mathrm{~mol}^{-1}
\end{aligned}
$$

The extent of the above reactions, the products distribution and the producer gas composition is a function of gasification conditions, such as gasification temperature, oxidant/biomass ratio, biomass composition and the residence time of the biomass particle in the reactor. 


\section{Biomass Integrated Gasification/Gas Turbine Combined Cycle (BIG/GTCC) in the sugar industry}

A primary advantage of biomass gasification over biomass direct combustion for electricity generation applications is that the power generation efficiency of a gas turbine combined cycle system is higher than the efficiency of biomass combustion processes that uses a steam cycle alone. Other advantage of the gasifying process is that a difficult solid fuel, like wood and wood residuals, is converted into a readily handled and easily burned fuel gas.

The principal requirement that hinders the implementation of this technology in sugar mills, is that the water content of feedstock should be in the 10-20\% range in order to realize cold gas efficiencies above 70\% [12]. This requirement makes the feedstock preparation one of the major problems that prevent its large-scale application in the sugar industry, considering that the sugarcane bagasse has a high humidity content when produced in the mill. Therefore, it is imperative to carry out a pre-treatment process to upgrade these biomass characteristics, in order to use this biomass as fuel for fluidized bed or entrained bed gasification, requiring additional energy consumption [13].

Some researches has shown the potential of Biomass Integrated Gasification Gas Turbine Combined Cycle (BIG/GTCC) based systems to be competitive with, if not superior to, conventional combustion power plants because of their higher efficiency, superior environmental performance, and competitive cost [14-16]. However much of the advancements are still under research and development.

BIG/GTCC is a combination of two leading technologies: the gasification, and the gas turbine combined cycle. The gasification stage of the BIG/GTCC plant produces a gas that feed gas turbine.

Typical operating temperature of a fluidized bed is $1073-1123 \mathrm{~K}$, using air as gasification agent. Air is blown through the bed at a sufficient velocity to keep the bed materials in a state of suspension. The fuel particles introduced to the reactor, are mixed very quickly with the bed material and almost instantaneously are heated up to the bed temperature and gasified.

In an entrained flow gasifier, the fuel is be injected together with oxygen, mixtures of steam and oxygen or air. There is a zone where most of the molten slag is collected. The products leaving the reactor at high temperatures and the fuel gas require a cooling process prior to cleaning.

After the producer gas leaves the gasifier, it goes through a cleaning unit where is cleaned of solids, tars, and other contaminants, sufficiently for the gas turbine requirements. After the cleaner unit, the gas is led to a boost compressor that compresses it to the pressure conditions of the gas turbine combustion chamber.

The exhaust heat from the gas turbine is recovered in the Heat Recovery Steam Generator (HRSG) in order to produce steam. This steam then passes through turbine to power another generator, which produces more electricity and the steam from the turbine extraction is used to satisfy the process requirements.

\subsection{Methodology for the technical analysis}

The technical analysis of the implementation of the BIG-GTCC in the sugar industry in Brazil, consider, as the baseline of the study, the configuration of a conventional sugar mill. The study evaluated the implementation of three different configurations, that ensuring demand for steam of the cogeneration plant.

In all cases, are determined the generation efficiencies of electricity, process heat, mechanical energy; and the overall efficiency.

In the final stage, was performed a comparison taking into account the thermodynamic efficiency of different cases and the technical possibilities of the implementation of each one to determine the best, from the technical point of view was performed. Fig. 2 shows the technical analysis methodology for incorporation of BIG-GTCC in the sugar mill.

The incorporation of sugarcane bagasse gasification in the sugar industry could be partial or pure. The "partial" implementation, keeps the existing cogeneration system at the plant and only is gasified the surplus bagasse of the process. In the case of "pure" implementation, the BIG-GTCC system replaces the conventional cogeneration system CEST. It is necessary, that after the incorporation of BIG-GTCC system on partial or pure way, the steam generation of the cogeneration plant, ensure thermal requirements of the process.

\subsection{Implementation of the "pure" BIG/GTCC system in the sugarcane industry}

The sugarcane baseline, where will be implemented the BIG/ GTCC technology, have a processing capacity of $276.9 \mathrm{t} \mathrm{h}^{-1}$ of sugarcane in the harvesting season. This plant produces $78.9 \mathrm{t} \mathrm{h}^{-1}$ of sugarcane bagasse with humidity content between 45 and $50 \%$ wet basis, of which $70.5 \mathrm{t} \mathrm{h}^{-1}$ are combusted in a boiler, designed to generate nominally $150 \mathrm{t} \mathrm{h}^{-1}$ of steam at a pressure of $6468 \mathrm{kPa}$ and temperature of $803 \mathrm{~K}$. The plant has a turbo generator that is capable of generates up to 40 MVA of electricity nominally with a multistage extraction-condensing steam turbine, that produces 19.12 MW. The thermal and mechanical energy consumed in the sugar production process are 88.707 MW and 3.919 MW respectively.

The feedstock (bagasse) is composed of fiber and water-soluble materials, mainly sugar and impurities. The fiber composition has an average composition of $50 \%$ cellulose, $25 \%$ hemicellulose and $25 \%$ lignin [17]. Table 1 shows the main properties of sugar cane bagasse reported by several authors).

The bagasse is classified as a fuel with high reactivity due to its high content of volatiles and low ash content, making of this biomass, a good feedstock for gasification.

For the implementation of the "pure" BIG/GTCC cycle in this sugar mill, the steam produced in the HRSG from the heat of the exhaust gases of the gas turbine must satisfy the high-pressure steam requirements for the process; was considered that the energy consumed by the pumps associated to the HRSG are equal to the consumed in the conventional configuration, i.e. 0.605 MW (see Table 2).

\subsubsection{Case 1. Gasification of bagasse in bubbling fluidized bed and} replacement the conventional boiler by BIG-GTCC system (BIG-GTCC "pure")

In this case, is analyzed the gasification of the sugarcane bagasse in bubbling fluidized bed gasifier and the replacement of the boiler in the conventional configuration by the gasifier-gas turbine-HRSG system, (BIG-GTCC "pure"), using drying process as pretreatment of the wet bagasse. Fig. 3 shows a scheme of the implementation of a "pure" BIG/GTCC system in the baseline sugar industry.

The energetic analysis was based in the First Law of Thermodynamics considering the process in steady state. Was also considered, based in the mean composition of sugarcane bagasse shows in Table 1 that the air stoichiometric ratio ( $\mathrm{kg}$ air/kg sugarcane bagasse) was 4.36 .

Fig. 4 shows the mass and energy balances on sugarcane bagasse dryer according to the experimental results reported by Prins et al. [27].

Equations (5) and (6) present the dryer energy balance on sugarcane bagasse dryer according to the control volume shows in Fig. 5: 


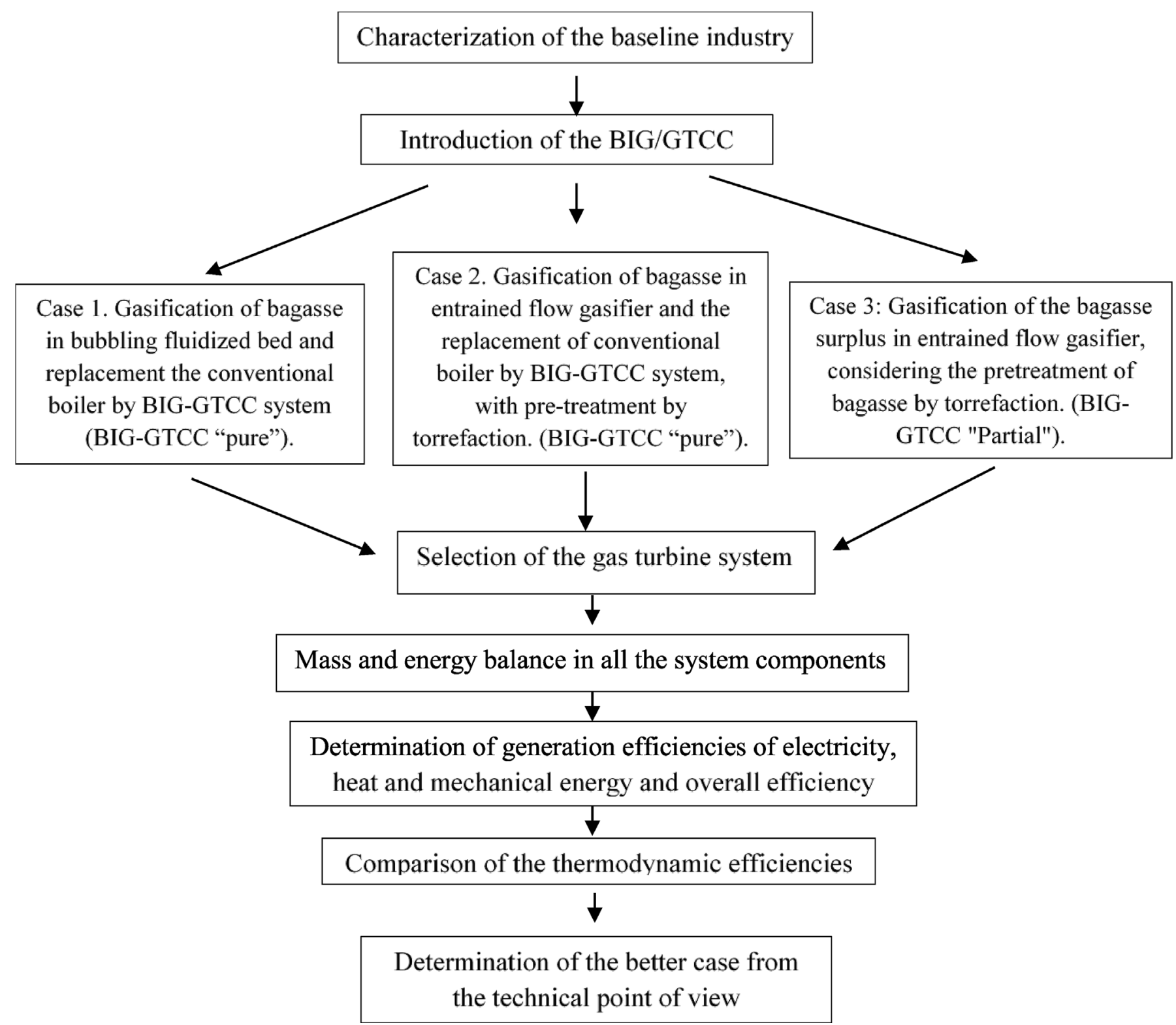

Fig. 2. Technical analysis methodology for incorporation of BIG-GTCC in the sugar mill.

Table 1

Main physical and chemical properties of sugar cane bagasse.

\begin{tabular}{|c|c|c|c|c|c|c|c|c|c|}
\hline & Ref [18] & Ref [19] & Ref [20] & Ref [21] & Ref [22] & Ref [23] & $\operatorname{Ref}[24]$ & Ref [25] & $\operatorname{Ref}[26]$ \\
\hline \multicolumn{10}{|l|}{ Proximate analysis } \\
\hline Volatile matter (wt.\%, dry basis) & 87.06 & 83.0 & 85.61 & 83.0 & 88.7 & 82.1 & 85.43 & 79.35 & n.a \\
\hline Fixed carbon (wt.\%, dry basis) & 12.94 & 13.0 & 11.95 & 13.0 & 9.3 & 16.3 & 12.89 & 17.88 & n.a \\
\hline Ash (wt.\%, dry basis) & n.a. & 4.0 & 2.44 & 1.9 & 2.0 & 1.6 & 1.68 & 3.66 & 6.8 \\
\hline Higher heating value (MJ. $\mathrm{kg}^{-1}$, dry basis) & 18.6 & 18.9 & 18.99 & n.a & 18.7 & 19.19 & 19.14 & 19.41 & 18.85 \\
\hline \multicolumn{10}{|l|}{ Ultimate analysis (wt.\%, dry basis) } \\
\hline $\mathrm{C}$ & 47.0 & 46.3 & 48.65 & 45.48 & 42.9 & 48.81 & 49.0 & 48.4 & 46.7 \\
\hline $\mathrm{H}$ & 5.9 & 6.4 & 5.87 & 5.70 & 5.9 & 6 & 5.87 & 6.01 & 6.2 \\
\hline O (by difference) & 45.81 & 43.0 & 42.82 & 45.21 & 49.0 & 43.1 & 43.27 & 41.61 & 39.8 \\
\hline $\mathrm{N}$ & 0.33 & n.a. & 0.16 & 0.40 & 0.20 & 0.46 & 0.1 & 0.17 & 0.2 \\
\hline$S$ & 0.05 & 0.1 & 0.04 & 0.06 & n.a. & 0.1 & 0.06 & 0.02 & 0.02 \\
\hline $\mathrm{Cl}$ & n.a. & n.a & 0.03 & n.a. & n.a & $<0.01$ & 0.02 & n.a & 0.06 \\
\hline
\end{tabular}


Table 2

Considerations for the energetic analyze.

\begin{tabular}{lll}
\hline Parameters & Values & Units \\
\hline$\eta_{\text {HRSG }}$ & 70 & $\%$ \\
$\mathrm{R}_{\mathrm{g}}$ & 0.29 & $\mathrm{~kJ} / \mathrm{kg} \cdot \mathrm{k}$ \\
$\eta_{\text {compressor }}$ & 80 & $\%$ \\
$\eta_{\text {tgiso }}$ & 89 & $\%$ \\
$\eta_{\mathrm{CC}}$ & 95 & $\%$ \\
$\Delta \mathrm{P}_{\mathrm{CC}}$ & 0.05 & $\mathrm{kPa}$ \\
$\Delta \mathrm{P}_{\text {HRSG }}$ & 0.05 & $\mathrm{kPa}$ \\
$\eta_{\mathrm{e}}$ & 95 & $\%$ \\
\hline
\end{tabular}

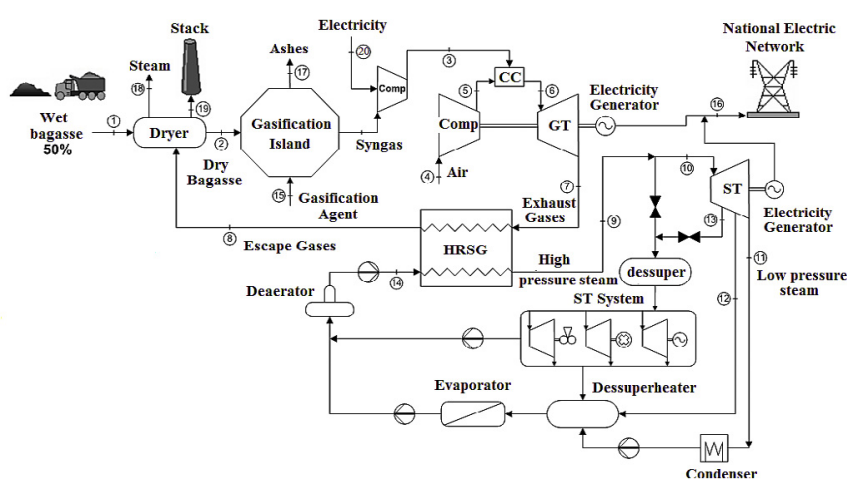

Fig. 3. Simplified scheme of a biomass integrated-gasification/gas turbine combined cycle (BIG/GTCC) system. (BIG-GTCC "pure").

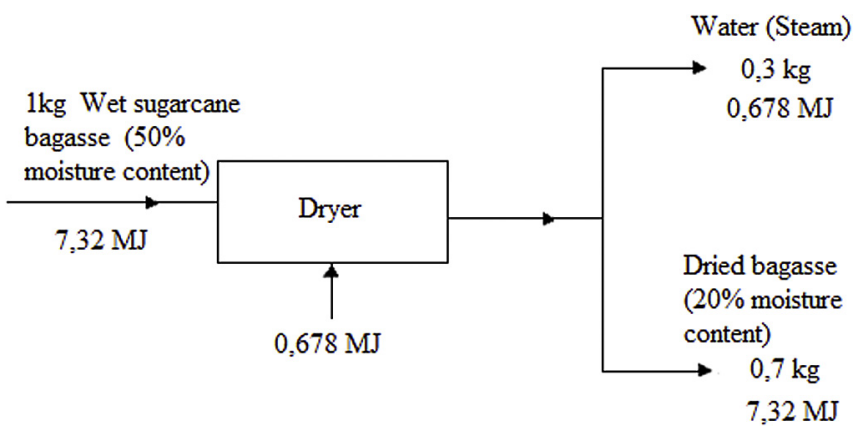

Fig. 4. Mass and energy balances on sugarcane bagasse dryer.

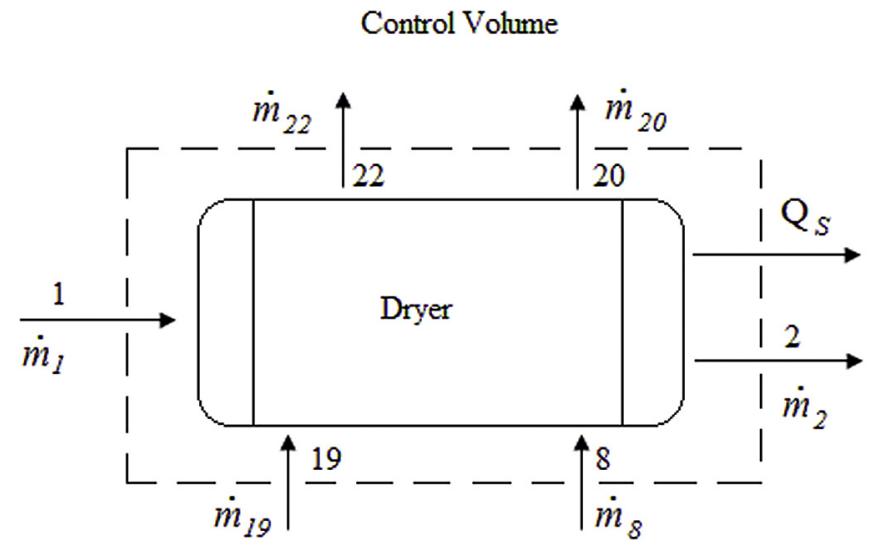

Fig. 5. Control volume of sugarcane dryer.

$$
\begin{gathered}
\dot{m}_{1} \cdot L H V_{\text {wbg }}+Q_{e g}=\dot{m}_{2} \cdot L H V_{d b g}+\dot{m}_{\text {steam }} \cdot h_{\text {steam }}+\dot{m}_{2} \cdot C p_{d b g} \cdot \Delta T \\
+Q_{s} \\
Q_{e g}=\dot{m}_{8} \cdot C p_{e g} \cdot \Delta T-\dot{m}_{19} \cdot C p_{\text {eg }} \cdot \Delta T
\end{gathered}
$$

Fig. 6 shows the interconnection between the installations that compose the Gasification Island, formed by the air blower, the BFBG and the producer gas conditioning system.

Fig. 7 shown the main mass and energy fluxes in the BFBG for the balances in the studied case.

The energy balance in a gasifier using air, oxygen, steam or its mixtures as gasification agent can be determined by Equation (7) $[27,28]$ :

$$
\begin{array}{rl}
\dot{m}_{\text {fuel }} L & L V_{\text {fuel }}+\dot{m}_{\text {air }} \Delta h_{\text {air }}+\dot{m}_{\mathrm{O}_{2}} \Delta h_{\mathrm{O}_{2}}+\dot{m}_{\mathrm{H}_{2} \mathrm{O}}\left(h_{v e}+\Delta h_{\mathrm{H}_{2} \mathrm{O}}\right) \\
= & \dot{m}_{P G a s}\left(\Delta h_{P G a s}+L H V_{P G a s}\right)+\dot{m}_{\text {Char }}\left(\Delta h_{\text {char }}+L H V_{\text {char }}\right) \\
& +\dot{m}_{\text {ashes }} \Delta h_{\text {ashes }}+Q_{G}
\end{array}
$$

Considering air at standard conditions as gasification agent, and that the gasification occurs at Carbon Boundary Point, i.e. when it is incorporated into the exact amount the gasification agent, ensuring complete gasification of the fuel with no char formation; the energy balance in the analyzed system (Fig. 7) is defined as follows:

$$
\begin{aligned}
\dot{m}_{2} \cdot L H V_{d b g}+\dot{m}_{a i r} \Delta h_{a i r}= & \dot{m}_{4}\left(\Delta h_{P G a s}+L H V_{P G a s}\right)+\dot{m}_{5} \Delta h_{\text {ashes }} \\
& +Q_{G}
\end{aligned}
$$

The cold gas efficiency using air as gasification agent is given by Equation (9):

$\eta_{\text {gasifier }}=\left(\frac{\dot{m}_{4} \cdot L H V_{P G a s}}{\dot{m}_{2} \cdot L H V_{d b g}+\dot{m}_{a i r} \Delta h_{a i r}}\right)$

The $\eta_{\text {gasifier }}$ of the BFBG in this case was considered $75 \%$, a high gasification efficiency for this type of reactors, considering the experimental results reported by several authors [29-32].

The gas turbine selection is performed according to the methodology reported by Antunes, J. [33], using available equipment in the market [34], with an exhaust gas temperature in the range of 773-948 K. In order to keep the mill processes unchanged, the steam parameters at the boiler exit in the CEST configuration must be the same at the exit of the HRSG in the "pure" BIG/GTCC configuration. The gas turbine selection considered an efficiency of the HRSG of 70\%, the enthalpy of the fluid at the HRSG entrance (point 14 in Fig. 3) as $454.1 \mathrm{~kJ} \mathrm{~kg}^{-1}$ and the steam enthalpy at exit (point 9 in Fig. 3) as $3488.5 \mathrm{~kJ} \mathrm{~kg}^{-1}$. The exhaust gases temperature

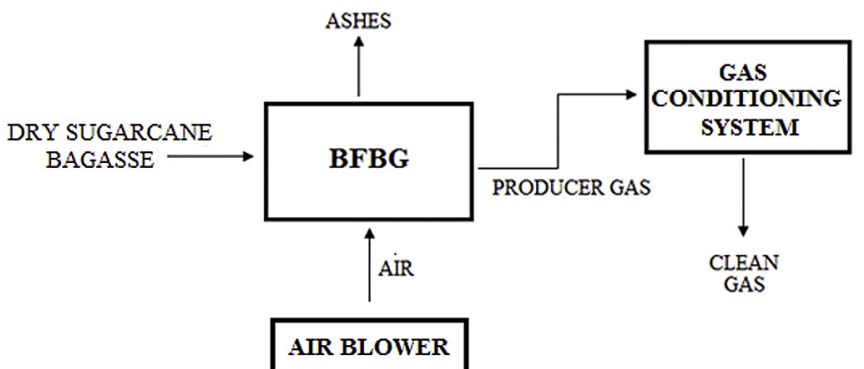

Fig. 6. Components of the Gasification Island using a Bubbling Fluidized Bed Gasifier (BFBG). 


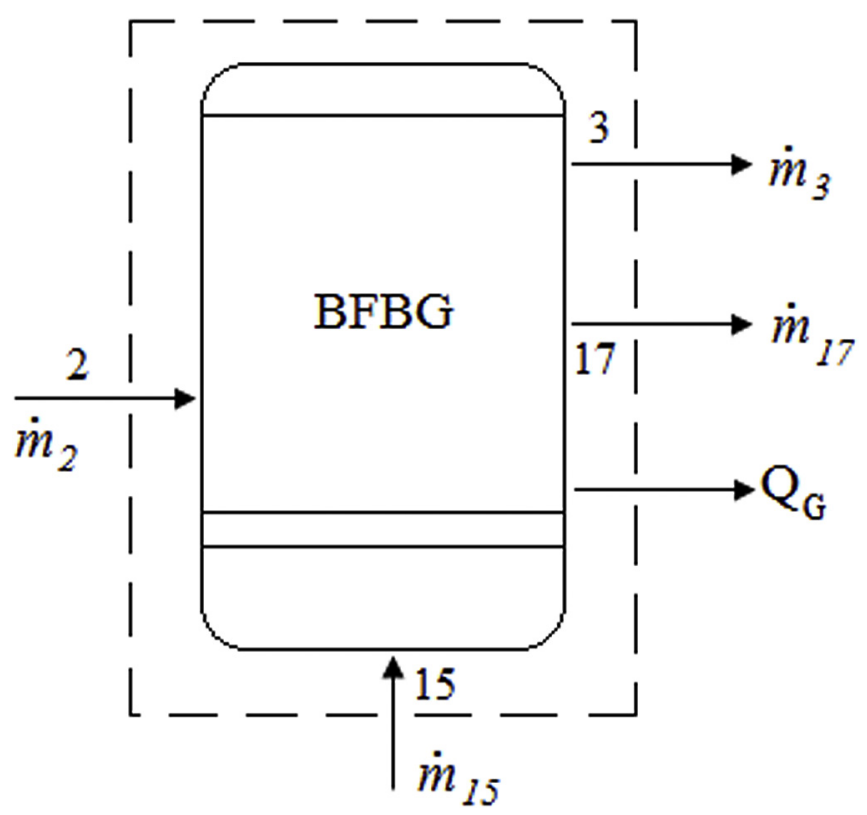

Fig. 7. Main mass and energy fluxes in the BFBG.

must be considered higher than $473 \mathrm{~K}$ at the HRSG exit (point 8 in Fig. 3) to avoid condensation problems [35].

The selected gas turbine must have sufficient exhaust gas flow to maintain the steam generation at the HRSG in order to satisfy the energy requirements of the plant.

The selected gas turbine was the Siemens Energy [60 Hz] (model SGT6-5000F) and the operating parameters of the gas turbine were corrected to the following real operating conditions:

- Temperature of $25^{\circ} \mathrm{C}$;

- Altitude of $760 \mathrm{~m}$;

- Relative humidity of $60 \%$.

Table 3 shows the characteristics of the selected gas turbine for the local operating conditions.

A gas turbine work can be defined as the product of mass flow, heat energy in the combusted gas and temperature differential across the turbine. Although there is no clear relationship between fuel lower heating value (LHV) and gas turbine power output, it is possible to make some general assumptions. If the fuel consists only of hydrocarbons with no inert gases and no oxygen atoms, output increases as LHV increases. Here the effects of heat energy in the combusted gas are greater than the effects of mass flow. In addition, as the amount of inert gases is increased, the decrease in LHV will provide an increase in power output [36].

Fuel gas with a large amount of inert components [such as carbon dioxide $\left(\mathrm{CO}_{2}\right)$ or nitrogen $\left(\mathrm{N}_{2}\right)$ ] have a low Wobbe index

Table 3

Characteristics of the gas turbine Siemens Energy [60 Hz], (model SGT6-5000F) in simple cycle (SC)

\begin{tabular}{ll}
\hline Parameter & Value \\
\hline Efficiency (\%) & 38.0 \\
Output (MW) & 176.03 \\
Heat Rate (Btu $\left.\mathrm{kWh}^{-1}\right)$ & 7805.0 \\
Rotation speed $(\mathrm{rpm})$ & 3600 \\
Compression ratio & 17.2 \\
Exhaust gas flow $\left(\mathrm{kg} \mathrm{s}^{-1}\right)$ & 477.29 \\
Exhaust temperature $[\mathrm{K}]$ & 883.47 \\
\hline
\end{tabular}

(WI) while substances with a large amount of heavier hydrocarbons have a high WI (Equation (10)), where SG is the relative density of the analyzed gas. For low heating value producer gas, WI range 5-13 MJ. Nm${ }^{-3}$ while for natural gas in similar thermodynamics conditions the WI range [37] 48-53 MJ. $\mathrm{Nm}^{-3}$.

$W I=\frac{L H V}{\sqrt{S G}}$

In general, engines will provide slightly more power output if the Wobbe index is reduced. This is because the amount of fuel mass flow increases for a given amount of fuel energy when reduced the Wobbe index. This increases the mass flow though the turbine section, which increases the power output of the turbine. This is the major impact of IGCC type fuels that have large amounts of inert gas in the fuel [38]. This mass flow addition, which is not compressed by the gas turbine's compressor, increases the turbine power output. Compressor power is essentially unchanged.

In most cases of operation with lower heating value fuels, it can be assumed that power output and efficiency of the gas turbine will be equal to or higher than that obtained on natural gas [36].

To satisfy the steam requirements of the mill using the Siemens Energy [60 Hz], (model SGT6-5000F), firing producer gas, a gasification island with nominal capacity of $600 \mathrm{MW}_{\text {th }}$ or higher is necessary, because most commercial-scale gasification islands have a cold gas efficiency of at least $[39,40] 65 \%$; in some cases exceed $80 \%$. Note that the cold gas efficiency does not account for the sensible heat available in the syngas, only the chemical energy available.

Special combustors developed by some gas turbine manufacturers can handle cleaned gasified solid and liquid fuels. Burners have been developed for medium heating value fuel (16-20 MJ. $\mathrm{Nm}^{-3}$ ), which is produced in oxygen-blown gasifiers, and for low heating values fuel $\left(3-5 \mathrm{MJ} . \mathrm{Nm}^{-3}\right)$, which is produced in air-blown gasifiers. These special combustors were developed principally for large gas turbines and are not found on small gas turbines [41].

The reduction in the system electric generation efficiency when lower heating value fuels is used, is basically originated by the additional energy required for the fuel compression, impacting mainly micro-turbines. To avoid this fact, new technology is introducing where, both, producer gas and air are compressed together in the compressor. This does away with the necessity of a costly and inefficient fuel compressor [42].

In the study was considered a reduction of $15 \%$ compared to the Gas turbine electricity generation efficiency when Natural Gas is used, based on previous studies $[2,41,42]$. The energy consumed by the producer gas compressor in this configuration $(0.80 \mathrm{MW})$ was calculated according [42].

Table 4 shows the plant operating parameters for the implementation of the BIG-GTCC "pure" in the mill.

For the calculus of the electricity generation efficiency was used Equation (11), considering the electricity generated in the mill, the energy consumed by the pump of the HRSG and by the producer gas compressor.

$\eta_{G E}=\frac{E_{t g e}+E_{t v e}-W_{b}-W_{L H V}}{E_{c o m b}}$

The global efficiency was calculated by Equation (12), considering also the mechanical and thermal energy consumed in the sugar production process.

$\eta_{G l}=\frac{E_{\text {tge }}+E_{t v e}+Q_{P r o c}+W_{M e c}-W_{b}-W_{L H V}}{E_{c o m b}}$

Table 5 shows a comparison of the generation efficiencies of 
Table 4

Results of the energetic analyze for the implementation of the BIG-GTCC "pure" in the mill.

\begin{tabular}{|c|c|c|c|c|}
\hline Point & Mass flow $\left[\mathrm{kg} \mathrm{s}^{-1}\right]$ & Temperature [K] & Pressure [kPa] & Energy flow [MW] \\
\hline 1 & 80.58 & 298 & 101.3 & 589.9 \\
\hline 2 & 56.39 & 298 & 101.3 & 589.9 \\
\hline 3 & 116.2 & 298 & 1931 & 442.4 \\
\hline 4 & 352.45 & 298 & 101.3 & - \\
\hline 5 & 352.45 & 791 & 1931 & - \\
\hline 6 & 468.65 & 1563 & 1834 & 442.4 \\
\hline 7 & 468.65 & 860 & 107 & 274.94 \\
\hline 8 & 468.65 & 544 & 101.3 & 132.58 \\
\hline 9 & 41.67 & 803 & 6468.0 & 145.4 \\
\hline 10 & 33.53 & 803 & 6468.0 & 116.97 \\
\hline 11 & 5.75 & 315 & 8.5 & 14.82 \\
\hline 12 & 17.78 & 420.2 & 245.0 & 49.06 \\
\hline 13 & 10.0 & 699 & 2650.0 & 32.95 \\
\hline 14 & 41.67 & 379.8 & 8820.0 & 18.92 \\
\hline 15 & 61.48 & 298 & 101.3 & - \\
\hline 16 & - & - & - & 167.23 \\
\hline 17 & 1.69 & 298 & 101.3 & 0 \\
\hline 18 & 24.19 & 373 & 101.3 & 64.73 \\
\hline 19 & 468.65 & 442.6 & 101.3 & 77.95 \\
\hline 20 & - & - & - & 0.80 \\
\hline
\end{tabular}

Table 5

Efficiencies of generation of electricity, heat, mechanical and overall energy and total power generated after the implementation of the BIG-GTCC "pure" in the mill.

\begin{tabular}{llllll}
\hline Technologies & $\eta_{g e}[\%]$ & $\eta_{\text {Qpr }}[\%]$ & $\eta_{\text {emec }}[\%]$ & $\eta_{g l}[\%]$ & Ete [MW] \\
\hline Conventional & 12.9 & 61.9 & 2.73 & 77.5 & 19.13 \\
BIG-GTCC & 27.8 & 12.9 & 0.57 & 43.5 & 167.23 \\
\hline
\end{tabular}

electricity, heat and mechanical energy, the overall efficiency and the total power generated, between the conventional configuration and when implemented the gasification of the BIG/GTCC "pure".

A variation in the gas turbine performance directly impact in the performance of the proposed configuration. Fig. 8 shows the effect of the variation of gas turbine electricity generation efficiency on electricity and global efficiency for the studied condition.
Is possible observe, that for the lowest gas turbine electricity generation efficiency, the electricity generation efficiency is $10 \%$ higher than in the conventional mill configuration.

The gasifier efficiency also is shows as a key parameter for the performance for this type of arrangement. Effects of gasification efficiency variation of on electricity generation efficiency and on sugarcane bagasse consumption (with humidity content between 45 and $50 \%$ wet basis) was also analyzed as shows in Fig. 9.

In the range of the cold gas efficiencies analyzed, for the lowest value evaluated, the electricity generation efficiency is twice the value obtained on the conventional configuration. The sugarcane bagasse requirements in this configuration is significantly high for the all cold gas efficiencies analyzed, ranging 3 to 4 times the total bagasse produced in the plant.

The required size of the gasification island is a principal obstacle

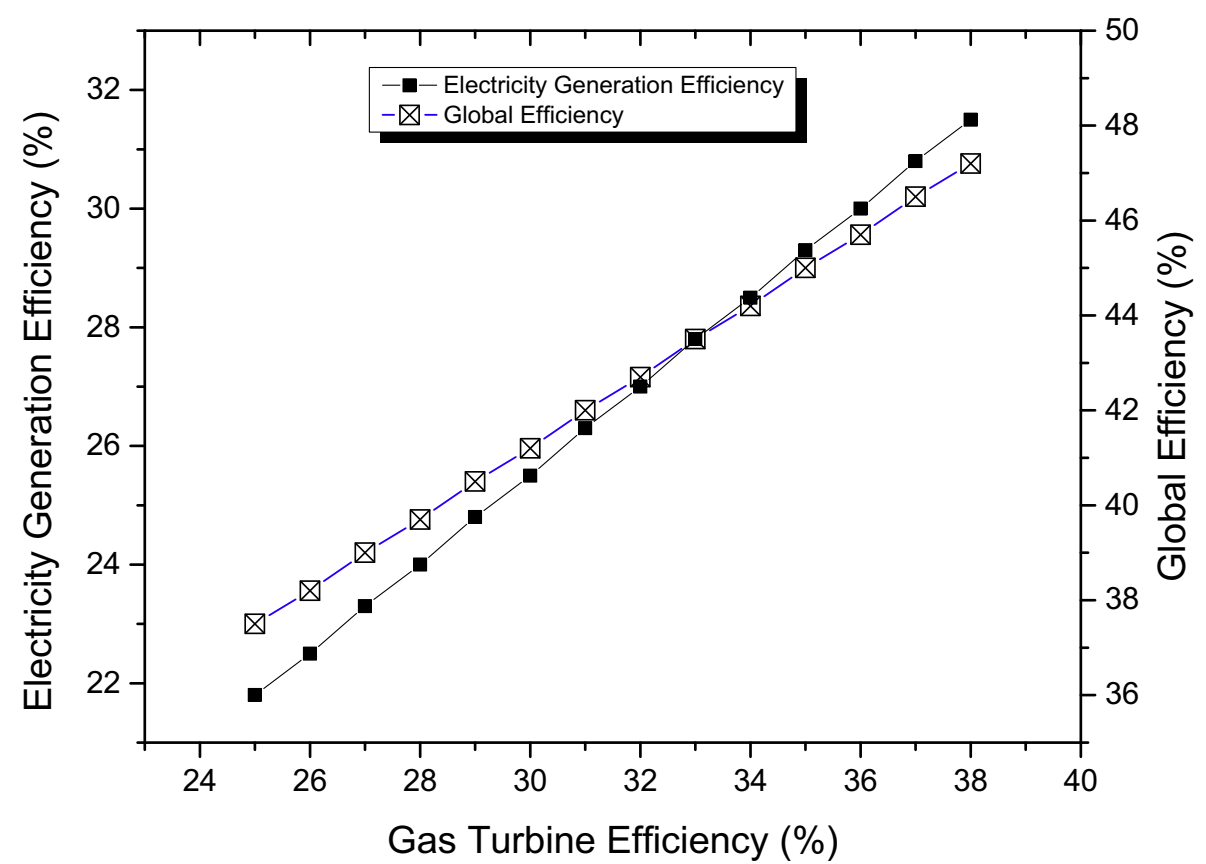

Fig. 8. Effect of variation gas turbine electricity generation efficiency on electricity and global efficiency on Case 1. 


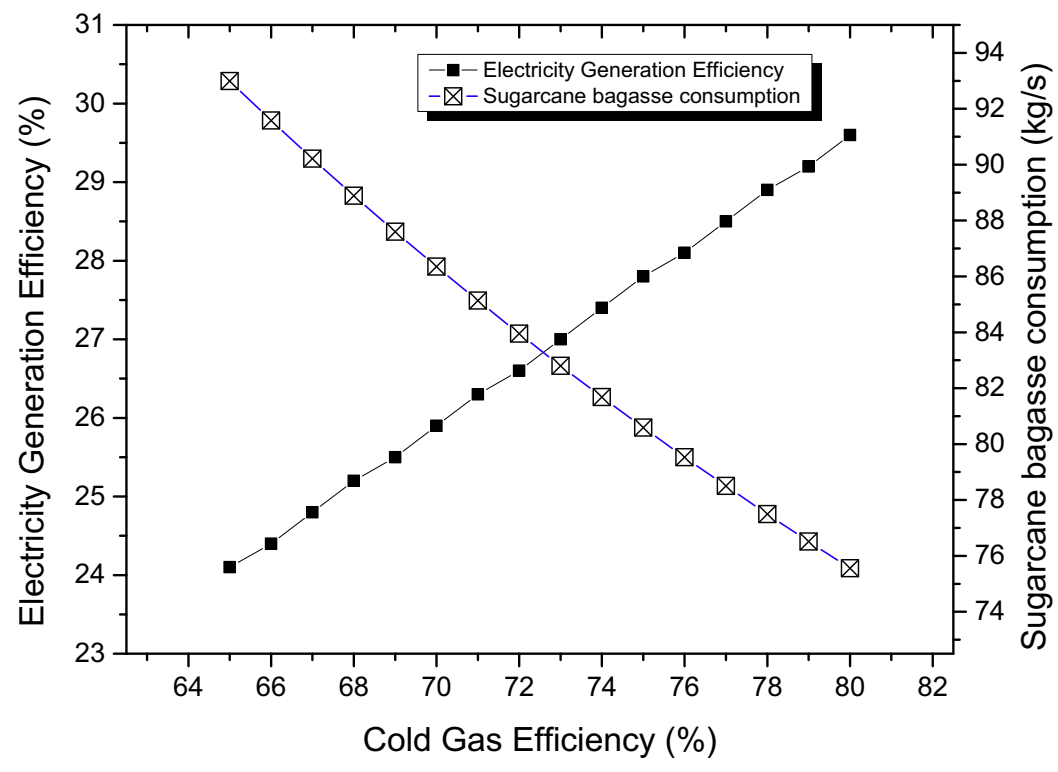

Fig. 9. Effect of variation of cold gas efficiency on electricity generation efficiency and on sugarcane bagasse consumption on Case 1 .

for the implementation of the "pure" BIG/GTCC in the baseline sugar mill, since the bigger biomass fluidized bed gasifier available at commercial scale, have a fraction of the required nominal capacity (Table 6). In addition, all the sugarcane bagasse produced in the mill represents $23.1 \%$ of the needed biomass to satisfy the feedstock demand of the gasification island.

On this context, the implementation of the "pure" BIG/GTCC in the studied sugar mill could be performed through one of the following configurations:

- Configuration 1: A biomass pretreatment unit able to dry $341.36 \mathrm{t} \mathrm{h}^{-1}$ of sugar cane bagasse up to $20 \%$ (w.b.) of water content, considering 50\% wet basis in the raw feedstock; a gasification island composed by seven Circulating Fluidized Bed (CFB) gasifiers, MILENA technology for biomass gasification, with a total nominal capacity of $700 \mathrm{MW}_{\mathrm{th}}$, and the producer gas cleaning systems. The gasification island is coupled to a gas turbine Siemens Energy [60 Hz], (model SGT6-5000F). In this configuration (Fig. 3), an external sugarcane bagasse supply of $211.19 \mathrm{t} \mathrm{h}^{-1}$ (with $50 \%$ humidity content wet basis) is needed (72.7\% of the total biomass required) to satisfy the feedstock requirements.

- Configuration 2: A biomass pretreatment unit able to dry $78.9 \mathrm{t} \mathrm{h}^{-1}$ of sugar cane bagasse up to $20 \%$ of water content, considering $50 \%$ wet basis in the raw feedstock. A gasification island composed by two Circulating Fluidized Bed (CFB) gasifiers, Foster Wheeler technology for biomass gasification, with a total nominal capacity of $160 \mathrm{MW}_{\mathrm{th}}$, and the producer gas cleaning systems. The gasification island is coupled to a gas turbine Siemens Energy [60 Hz], (model SGT6-5000F). In this configuration (Fig. 3), an external natural gas supply of $40.38 \mathrm{t} \mathrm{h}^{-1}$ (LHV for a gas natural of $47.14 \mathrm{MJ} \mathrm{kg}^{-1}[44,45]$ ) is needed $(72.79 \%$ of the total energy required) to satisfy the turbine feedstock requirements.

The dimensions of the proposed plant in both configurations is the principal obstacle for the economic viability of this configuration, considering an expected plant lifetime of 15 years $[39,40]$. The required external energy supply to satisfy the plant steam necessities in both cases $(72.79 \%)$ is also a serious problems for the implementation of the "pure" BIG/GTCC in the studied mill. If a sustainable and economical option to resolve these barriers is applied, there are still reported problems during handling, feeding, gasification and the producer gas cleaning, when using sugarcane bagasse as feedstock [46-48]. In addition, the Institute of Gas Technology (now GTI) in 1988 tested this technology at the Hawaiian Commercial \& Sugar Company's Paia sugar factory in Maui, Hawaii, using $100 \mathrm{t}^{\text {day }}{ }^{-1}$ of sugarcane bagasse as the feedstock to the gasification island. The project demonstrated limited success with air-blown gasification at about $2 \mathrm{MPa}$ (RENUGAS Process) and with the hot-gas filtration to remove carry-over dust. Serious problems were encountered in handling and feeding the shredded

Table 6

Principal commercial projects of biomass gasification islands [39,40,43].

\begin{tabular}{|c|c|c|c|c|}
\hline Project Name & Installation Year & Nominal Capacity $\left(\mathrm{MW}_{\mathrm{th}}\right)$ & Gasification Technology & Fuel \\
\hline Carbona & 2009 & 20 & BFB & Wood Pellets \\
\hline Foster Wheeler & 2001 & 40 & BFB & Plastics and demolition wood \\
\hline Energy Products Idaho & 1986 & 28 & $\mathrm{BFB}$ & Wood Chip \\
\hline Foster Wheeler (CFB) & 2009 & 160 & $(2)^{*} \mathrm{CFB}$ & Biomass \\
\hline VTT Finland & 2009 & 50 & CFB & Biomass \\
\hline $\mathrm{ECN}$ & 2014 & 100 & CFB & Wood \\
\hline CHOREN & 2013 & 640 & $(4) * E F G$ & Biomass \\
\hline Karlsruhe Institute of Technology & 2006 & 200 & $(3) * E F G$ & Biomass- Agriculture Residues \\
\hline Uhde PRENFLO Gasification & 1992 & Up to 1200 & EFG & Coal \\
\hline Westinghouse Plasma & 2010 & 130 & Plasma & Biomass, Waste \\
\hline
\end{tabular}


sugarcane bagasse into the gasifier; the project was terminated in 1997 [49].

To overcome the observed handling and feeding problems when sugarcane bagasse is used as feedstock in biomass gasifiers a second configuration is proposed in the next epigraph.

\subsubsection{Case 2: Gasification of bagasse in entrained flow gasifier and} the replacement of conventional boiler by BIG-GTCC system, with pre-treatment of bagasse by torrefaction. (BIG-GTCC "pure")

The principal difference of the Case 2, respect the previous analyzed configuration, is the use of torrefaction as pre-treatment process of bagasse, instead drying; and its gasification in an entrained flow gasifier instead a fluidized bed gasifier. The biomass torrefaction is an attractive pre-treatment process, in order to reduce the problems related to the low-density properties of the sugar cane bagasse. The torrefaction may largely improve the energetic properties of this biomass, its milling characteristics, as well as may have a positive impact on transport, handling and storage due to the hydrophobic nature and the physical structure acquired after the torrefaction. Due to the characteristics of the torrefied biomass, mainly heating value and grindability [50,51], its gasification can be carried out using gasification technologies designed to use coal as feedstock. An arrangement of both technologies constitutes the configuration of Case 2, as shown in Fig. 10.

In this configuration, the sugarcane bagasse is fed to the dryer to reduce the water content from $45-50 \%$ to $20-25 \% \mathrm{w}$. b. The bagasse is then fed to the torrefaction reactor and subsequently to the mill for the sizes reduction of the obtained torrefacted bagasse, which is fed to the gasification island. The volatiles obtained in the torrefaction reactor are also fed to the gasification island to increase the energetic efficiency of the process. The producer gas is then fed to the gas turbine for electricity generation. The gas turbine exhaust gases energy is used part to generate the required steam of the process at the HRSG and part to supply energy for the torrefaction process. A fraction of the sugarcane bagasse is fed to a burner to produce the energy required for the dryer and for the torrefaction process.

Fig. 11 shows the overall mass and energy balances for the torrefaction process of sugarcane bagasse at $250{ }^{\circ} \mathrm{C}$ for $30 \mathrm{~min}$, based on the experimental results reported by Pimchuai et al. [51]; it is considered that the provided bagasse has a moisture content of $20-25 \%$.

The concept of torrefaction-aided gasification is similar to twostage pyrolysis-gasification, but differs in two aspects. Firstly, the temperature of the torrefaction stage is carefully controlled at or below $573 \mathrm{~K}$ in order to minimize pyrolysis of cellulose and avoid

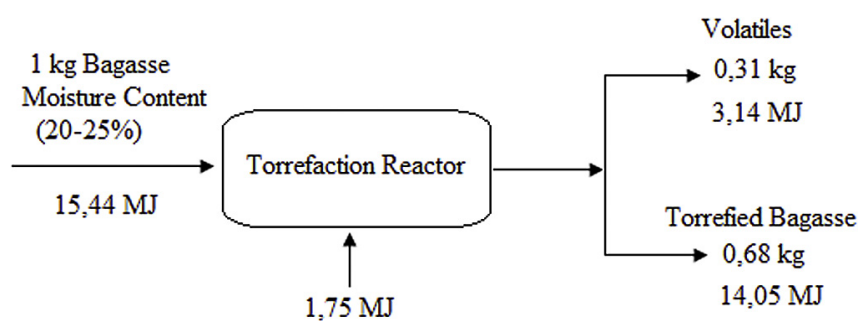

Fig. 11. Overall mass and energy balances for sugarcane bagasse torrefaction process a temperature and reaction time of $250{ }^{\circ} \mathrm{C}$ and $30 \mathrm{~min}$ (considering the HHV of sugarcane bagasse) [51].

tar formation. Secondly, the heat requirements for torrefaction are smaller than for pyrolysis at higher temperatures. Therefore, instead of taking heat from the gasifier itself (e.g. by recirculation of hot sand), sufficient heat can be taken from the flue gas as shown in Fig. 10.

It is possible to observe that after torrefaction, biomass contains $90 \%$ of the initial energy and $70 \%$ of the initial mass, and the volatiles contain $30 \%$ of mass and $10 \%$ of the raw fuel energy, causing an energetic densification of the solid product obtained.

The mass and energy balances was performed with base in the same considerations of the Case 1 . The energy balance of the torrefaction reactor is determinate by Equations (13) and (14), considering the control volume shows in Fig. 12.

Due to the improved quality of the torrefied sugarcane bagasse (mainly LHV and grindability), is possible to carryout its gasification in a reactor with a higher cold gas efficiency like the entrained flow gasifier (EFG). The cold gas efficiency in the EFG could reach $90 \%$ $[39,40]$. In this case the Gasification Isaland is compoused by an Entrained Flow Gasifier, a Cryogenic Air Separation Unit (CASU) and the producer gas conditioning system as shows in Fig. 13.

Fig. 14 shown the main mass and energy fluxes in the EFG for the balances in the studied case.

In this case the cold gas efficiency considered for the calculus was $79 \%$ and the energy balance is defined as follows:

$$
\begin{aligned}
\dot{m}_{2} \cdot L H V_{d b g}+Q_{G E}= & \dot{m}_{3} \cdot L H V_{\text {bgTorref }}+\dot{m}_{12} \cdot\left(\Delta h_{\text {voláteis }}\right. \\
& \left.+L H V_{\text {voláteis }}\right)+\dot{m}_{11} \cdot C p_{G E} \cdot \Delta T+\mathrm{Q}_{T}
\end{aligned}
$$

$$
Q_{G E}=\dot{m}_{7} \cdot C p_{G E C} \cdot \Delta T+\dot{m}_{8} \cdot C p_{G E T} \cdot \Delta T-\dot{m}_{11} \cdot C p_{G E} \cdot \Delta T
$$

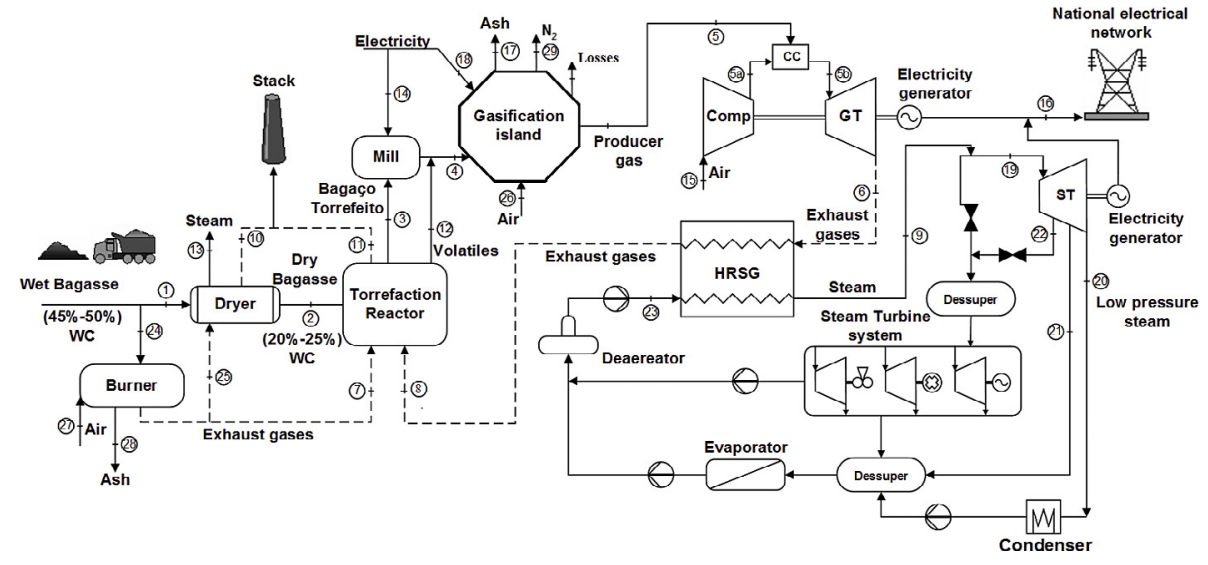

Fig. 10. Simplified schematic of a biomass integrated-gasifier/gas turbine combined cycle system with a torrefaction path (BIG-GTCC "pure"). 
Control Volume

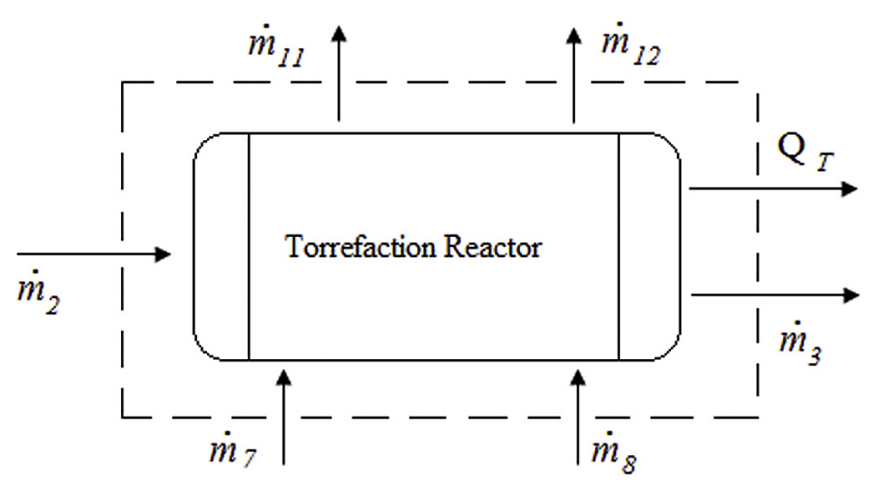

Fig. 12. Control volume of torrefaction reactor.

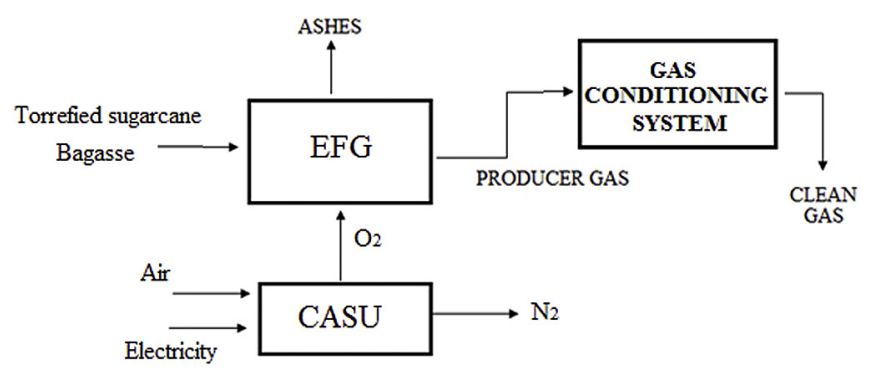

Fig. 13. Components of the Gasification Island using an Entrained Flow Gasifier (EFG).

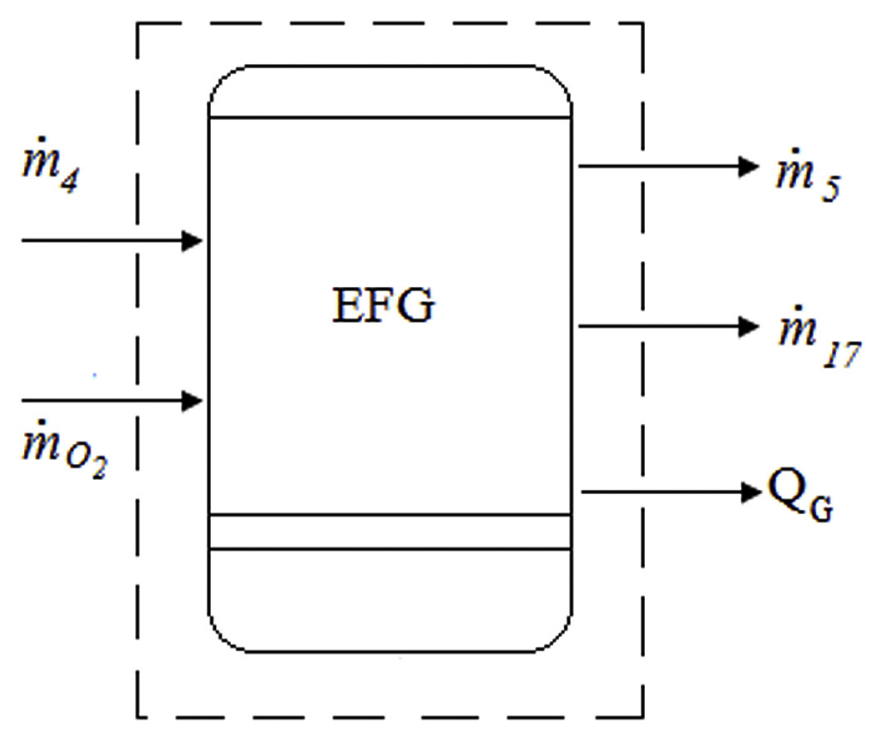

Fig. 14. Main mass and energy fluxes in the EFBG.

$$
\begin{aligned}
& \dot{m}_{3} \cdot L H V_{\text {bgTorref }}+\dot{m}_{12} \cdot\left(\Delta h_{\text {voláteis }}+L H V_{\text {voláteis }}\right) \\
& \quad=\dot{m}_{5}\left(\Delta h_{P G a s}+L H V_{P G a s}\right)+\dot{m}_{17} \Delta h_{A S H E S}+Q_{G}
\end{aligned}
$$

Table 7 shows the results of the mass and energy balances for the implementation of the BIG-GTCC "pure" with the inclusion of bagasse torrefaction as pretreatment process.

Table 8 shows the generation efficiencies of electricity, heat and mechanical energy and overall efficiency when implemented the gasification of the BIG/GTCC "pure" with pretreatment by torrefaction, considering the energy provided by the sugarcane bagasse.

For the calculus of the electricity generation efficiency in this case was used Equation (16), considering the electricity generated in the plant, the energy consumed by the pump of the HRSG, the producer gas compressor, the mill and the Cryogenic Air Separation Unit.

$\eta_{G E}=\frac{E_{t g e}+E_{t v e}-W_{b}-W_{L H V}-W_{\text {Mill }}-W_{C A S U}}{E_{c o m b}}$

The global efficiency was calculated by Equation (17), considering also the mechanical and thermal energy consumed in the sugar production process.

$\eta_{G l}=\frac{E_{t g e}+E_{t v e}+Q_{\text {Proc }}+W_{M e c}-W_{b}-W_{L H V}-W_{M i l l}-W_{C A S U}}{E_{c o m b}}$

In this case was also evaluated the effects of variations in the gas turbine efficiency in the performance of the proposed configuration. Fig. 15 shows the effect of the variation of gas turbine electricity generation efficiency on electricity and global efficiency for the studied condition.

In this configuration occur a sensible reduction in the global and electricity generation efficiency, mainly because of the increments in the electricity consumed by the auxiliary equipment of the systems.

The impact of the variation of cold gas efficiency on electricity generation efficiency and on sugarcane bagasse consumption (with humidity content between 45 and $50 \%$ wet basis) was also analyzed as shows in Fig. 16.

The analysis shows that for the range of the cold gas efficiencies evaluated, the sugarcane bagasse required for the implementation of this configuration is increased when compared to the Case 1 , with an associated reduction in the electricity and global efficiency; that's mean that for the implementation of this configuration, is needed a biomass pretreatment unit able to dry and torrefy $375.06 \mathrm{t} \mathrm{h}^{-1}$ of sugarcane bagasse, considering $50 \%$ of water content wet basis in the raw feedstock. Is also required a gasification island composed by an entrained flow gasifier, CHOREN's Carbo- $V^{\circledR}$ process technology, with a nominal capacity of $500 \mathrm{MW}_{\mathrm{th}}$, a Cryogenic Air Separation Unit (ASU), and producer gas cleaning systems. The gasification island is coupled to a gas turbine Siemens Energy [60 Hz], (model SGT6-5000F). In this configuration (Fig. 10), an external sugarcane bagasse supply of $264.92 \mathrm{t} \mathrm{h}^{-1}$ is needed (77.05\% of the total biomass required) to satisfy the feedstock requirements.

The principal obstacle for the viability for the implementation of the "pure" BIG/GTCC with this configuration is the required external energy supply to satisfy the plant steam necessities, equivalent to all the produced sugarcane bagasse of four sugar mill with similar processing capacity of the studied mill. In the sugar mills with smaller steam requirements, the Case 2 could be evaluated for the viability of its implementation. An increase of the electricity generation efficiency without a significant increase in the sugarcane bagasse requirements is the main objective of the case 3 analyzed in the next epigraph.

\subsubsection{Case 3. Implementation of the "partial" BIG/GTCC system in} the sugarcane industry

In this case the BIG/GTCC implementation will not affect the baseline configuration of the plant and use as feedstock the surplus bagasse of the plant, differently than the earlier cases. The implementation of the "partial" BIG/GTCC, combined with a sugarcane 
Table 7

Results of the mass and energy balances for the implementation of the BIG-GTCC "pure" with bagasse torrefaction.

\begin{tabular}{|c|c|c|c|c|}
\hline Point & Mass flow $\left[\mathrm{kg} \mathrm{s}^{-1}\right]$ & Temperature [K] & Pressure [kPa] & Energy flow [MW] \\
\hline 1 & 68.05 & 298 & 101.3 & 498.19 \\
\hline 2 & 47.64 & 333 & 101.3 & 498.19 \\
\hline 3 & 33.34 & 373 & 101.3 & 453.36 \\
\hline 4 & 47.64 & 373 & 101.3 & 553.01 \\
\hline 5 & 56.31 & 323 & 1931 & 442.40 \\
\hline 6 & 468.65 & 860 & 107 & 275.17 \\
\hline 7 & 10.74 & 1278.93 & 101.3 & 12.11 \\
\hline 8 & 468.65 & 544 & 101.3 & 132.58 \\
\hline 9 & 41.67 & 803 & 6468.0 & 145.4 \\
\hline 10 & 75.89 & 552.94 & 101.3 & 22.25 \\
\hline 11 & 479.39 & 474.04 & 101.3 & 97.05 \\
\hline 12 & 14.29 & 373 & 101.3 & 99.64 \\
\hline 13 & 20.42 & 373 & 101.3 & 54.64 \\
\hline 14 & - & - & - & 2.27 \\
\hline 15 & 412.34 & 298 & 101.3 & 0 \\
\hline 16 & - & - & - & 167.23 \\
\hline 17 & 2.88 & 298 & 101.3 & 0 \\
\hline 18 & - & - & - & 16.7 \\
\hline 19 & 33.53 & 803 & 6468.0 & 116.96 \\
\hline 20 & 5.75 & 316 & 8.5 & 14.82 \\
\hline 21 & 17.78 & 420.3 & 245 & 49.05 \\
\hline 22 & 10 & 699.3 & 2650.0 & 32.95 \\
\hline 23 & 41.67 & 380.1 & 8820.0 & 18.92 \\
\hline 24 & 15.19 & 298 & 101.3 & 111.25 \\
\hline 25 & 75.89 & 1278.93 & 101.3 & 76.89 \\
\hline 26 & 48.10 & 298 & 101.3 & 0 \\
\hline 27 & 71.66 & 298 & 101.3 & 0 \\
\hline 28 & 0.23 & 373 & 101.3 & 40.19 \\
\hline 29 & 36,55 & 298 & 101.3 & - \\
\hline
\end{tabular}

\section{Table 8}

Efficiencies of generation of electricity, heat, mechanical and overall energy and total power generated with the implementation of BIG/GTCC "pure" with pretreatment by torrefaction.

\begin{tabular}{llllll}
\hline Technologies & $\eta_{g e}[\%]$ & $\eta_{Q p r}[\%]$ & $\eta_{\text {emec }}[\%]$ & $\eta_{g l}[\%]$ & Ete [Mw] \\
\hline Conventional & 12.9 & 61.9 & 2.73 & 77.53 & 19.13 \\
BIG-GTCC & 23.9 & 12.7 & 0.56 & 39.1 & 167.23 \\
\hline
\end{tabular}

bagasse torrefaction, appear to be better alternative; due to the elevated investments and to the large external supply of energy required for the implementation of the studied "pure" - BIG/GTCC configurations. In the "partial" BIG/GTCC the existing cogeneration equipment at the mill, provides the process steam requirements. The "partial" BIG/GTCC configuration proposed for the studied mill is shown in Fig. 17.

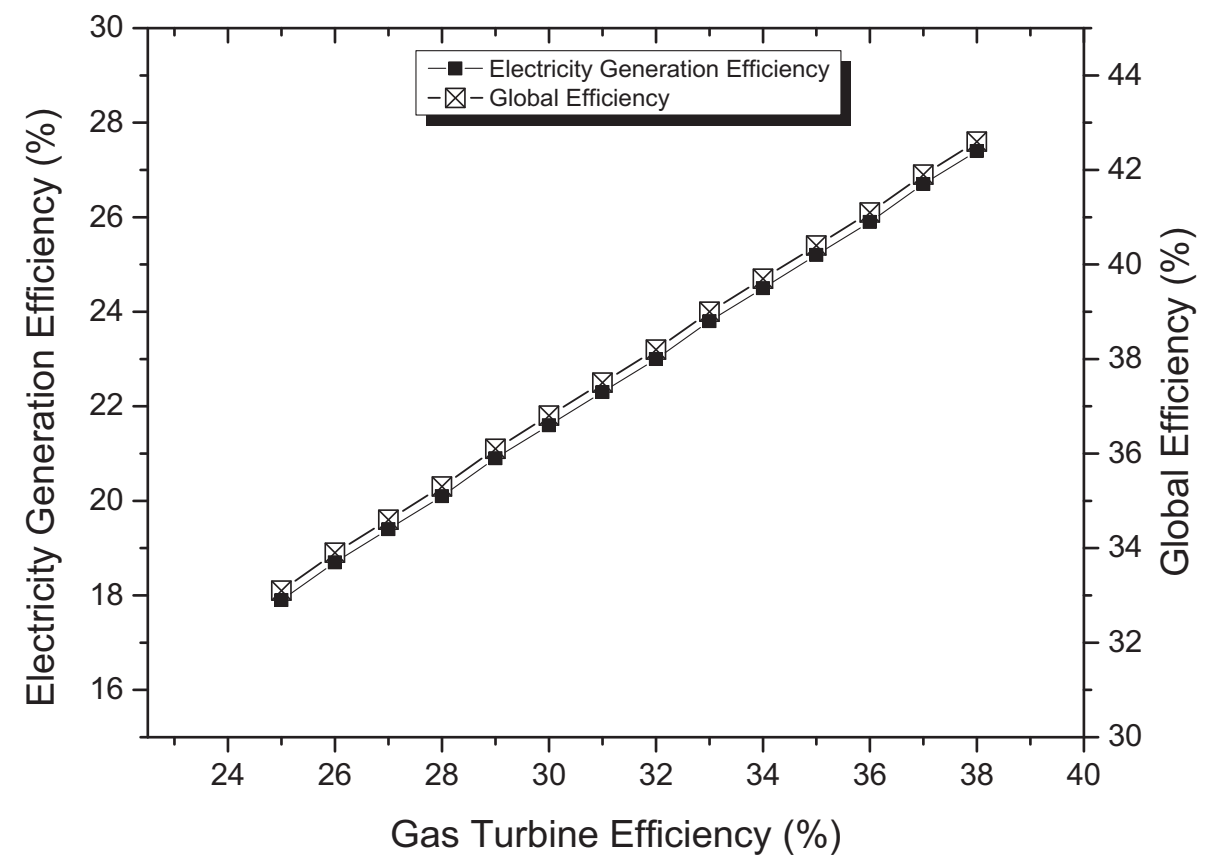

Fig. 15. Effect of variation gas turbine electricity generation efficiency on electricity and global efficiency on Case 2 . 


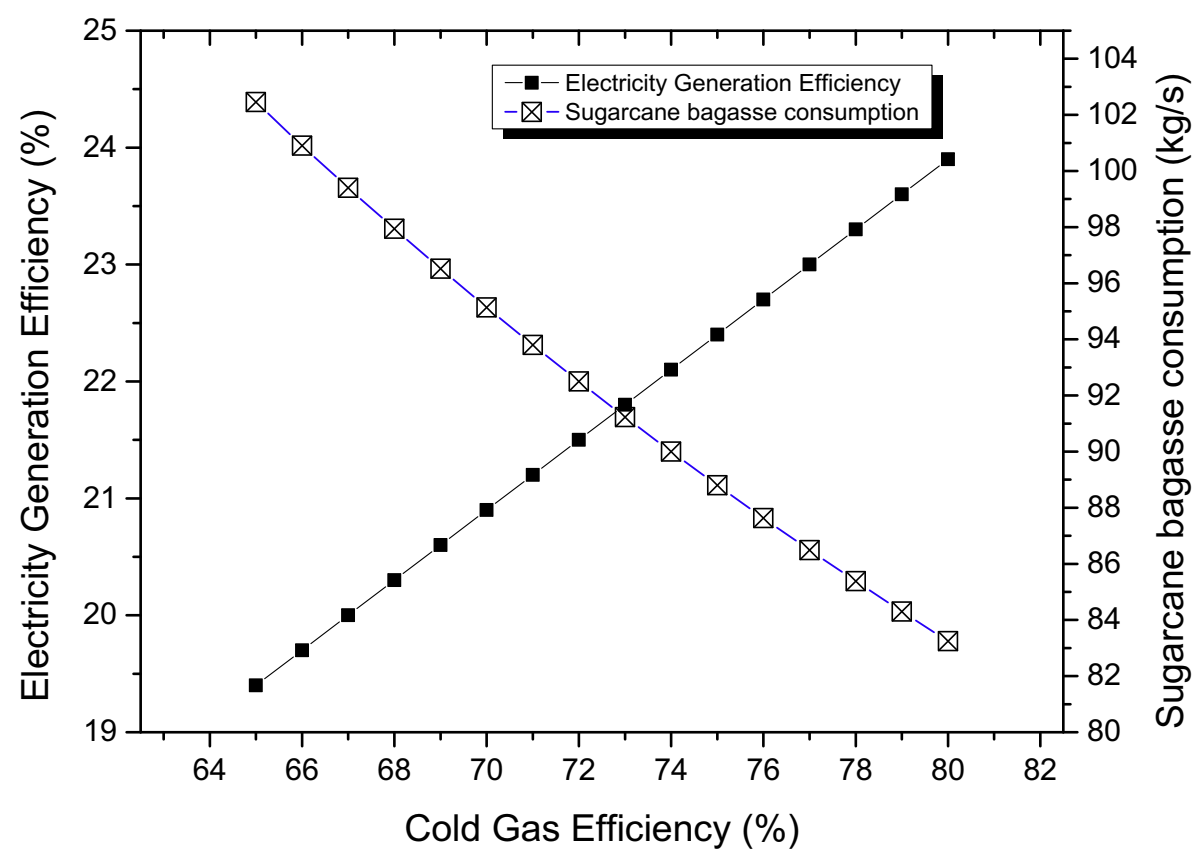

Fig. 16. Effect of variation of cold gas efficiency on electricity generation efficiency and on sugarcane bagasse consumption on Case 2 .

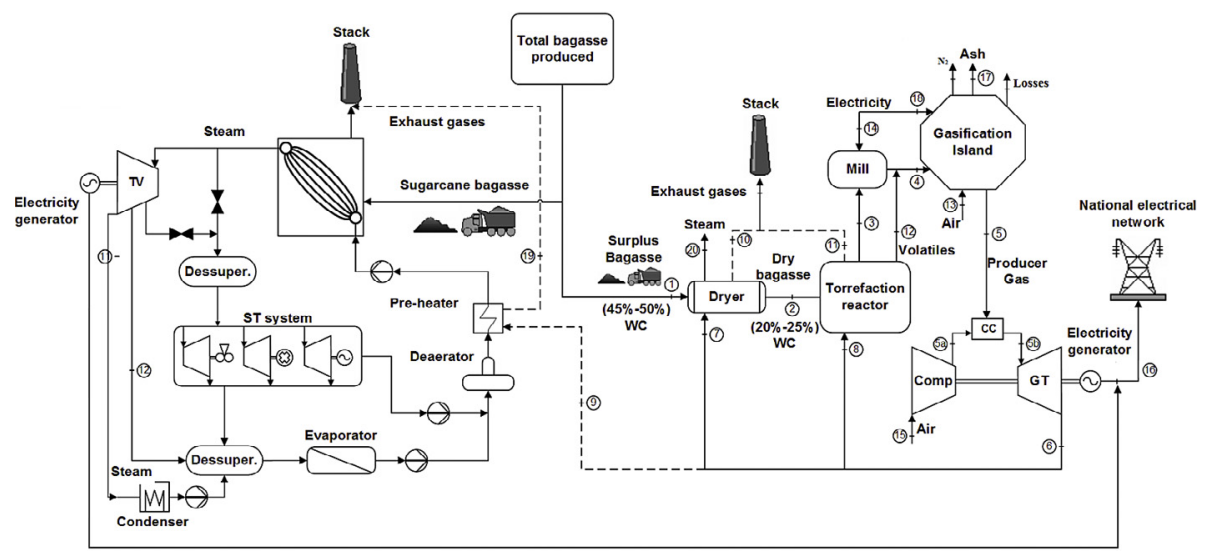

Fig. 17. Surplus bagasse gasification in entrained flow gasifier, considering the pretreatment of bagasse by torrefaction. (BIG-GTCC "Partial").

The installed boiler to generating $150 \mathrm{t} \mathrm{h}^{-1}$ of steam at $6468 \mathrm{kPa}$ and $803 \mathrm{~K}$ of temperature, and the turbo generator, generating 19.127 MW of electricity with the high-pressure steam from the boiler, with a multistage turbine of extraction and condensation; this facilities provides the process steam requirements. In parallel, a biomass pretreatment unit able to dry and torrefy $8.4 \mathrm{t} \mathrm{h}^{-1}$ of sugarcane bagasse, considering $50 \%$ of water content wet basis in the raw feedstock, to feed a gasification island. The gasification island is composed by an entrained flow gasifier, CHOREN Carbo- $V^{\circledR}$ process technology [52]; with a nominal capacity of $20 \mathrm{MW}_{\mathrm{th}}$, a Cryogenic Air Separation Unit (CASU), and the producer gas cleaning systems. The gasification island is coupled to a gas turbine Rolls Royce (model 501-KH5). (Fig. 17).

The "partial" BIG/GTCC configuration with a biomass torrefaction path as pretreatment process have several advantages over the "pure" BIG/GTCC configuration. This arrangement allows the electricity generation increment, without modifications in the existing mill facilities. The design dimensions of the BIG/GTCC arrangement will be only determined by the available sugarcane bagasse (surplus bagasse of the process or supplied by an external provider). The implementation of this configuration also allows the electricity generation in milling season and off season using another biomass as feedstock.

The mass and energy balances was performed with base in the same considerations of the Case 2 . The energy balance of the torrefaction reactor is determinate by Equations (18) and (19), considering the control volume shows Fig. 18.

Similarly to the considered in the Case 2 the improved quality of the torrefied sugarcane, the gasifier proposed is an the entrained flow gasifier (EFG); also the Gasification Isaland is compoused by an Entrained Flow Gasifier with a cold gas efficiency of 79\%, a Cryogenic Air Separation Unit (CASU) and the producer gas conditioning system as shows in Fig. 17. The main mass and energy fluxes in the EFG are similar to the shows in Fig. 14 and the energy balance is governing by Equation (15).

Table 9 reports the results of the mass and energy balances of the "partial" BIG/GTCC in the studied sugar mill, with the surplus sugarcane bagasse of the process $\left(8.4 \mathrm{t} \mathrm{h}^{-1}\right)$ with humidity content 


\section{Control Volume}

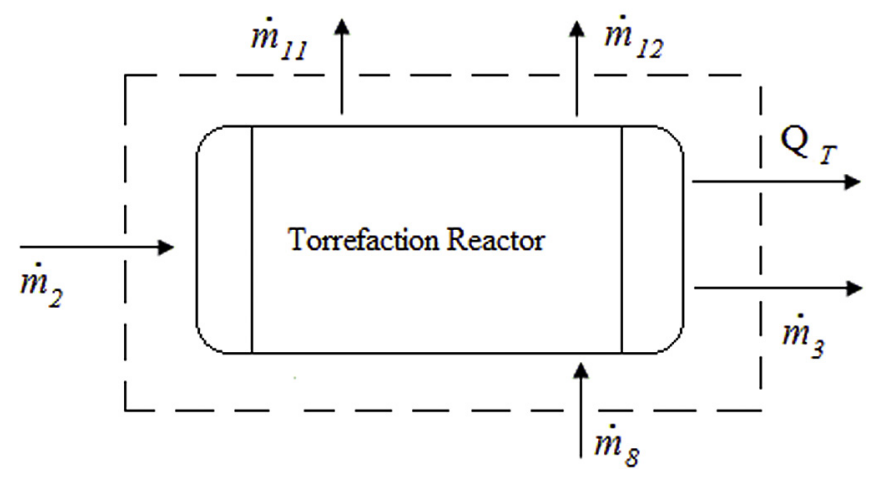

Fig. 18. Control volume of torrefaction reactor.

$$
\begin{aligned}
\dot{m}_{2} \cdot L H V_{d b g}+Q_{G E}= & \dot{m}_{3} \cdot L H V_{\text {bgTorref }}+\dot{m}_{12} \cdot\left(\Delta h_{\text {voláteis }}\right. \\
& \left.+L H V_{\text {voláteis }}\right)+\dot{m}_{11} \cdot C p_{G E} \cdot \Delta T+Q_{T}
\end{aligned}
$$

$Q_{G E}=\dot{m}_{8} \cdot C p_{G E T} \cdot \Delta T-\dot{m}_{11} \cdot C p_{G E} \cdot \Delta T$ case was used Equation (16), considering the electricity generated in the plant, the energy consumed by the pump of the boiler, the producer gas compressor, the mill and the Cryogenic Air Separation Unit. The global efficiency was calculated by Equation (17), considering also the mechanical and thermal energy consumed in the sugar production process.

Table 10 shows the efficiencies of generation of electricity, heat and mechanical energy and global when implemented the gasification of the BIG/GTCC "partial" with pretreatment by torrefaction, considering the energy provided by the sugarcane bagasse. The electricity generation efficiency in this case was $14.7 \%$.

Fig. 19 shows the impact of gas turbine efficiency variations in the in the performance of this configuration. Different to the previous studied cases, there is a small variation on electricity generation efficiency and global efficiency for the studied conditions, ranging up to $1.5 \%$ for both.

For the lower analyzed gas turbine efficiency, the electricity generation efficiency approaching to the efficiency obtained in the baseline configuration; not justifying the implementation of this configuration if is expected that the gas turbine have that efficiency.

The impact of the variation of cold gas efficiency on electricity generation efficiency and on sugarcane bagasse consumption (with humidity content between 45 and 50\% wet basis) was also analyzed as shows in Fig. 20.

Table 9

\begin{tabular}{|c|c|c|c|c|}
\hline Point & Mass Flow $\left(\mathrm{kg} \mathrm{s}^{-1}\right)$ & Temperature (K) & Pressure [kPa] & Energy flow [MW] \\
\hline $1^{\prime}$ & 2.33 & 298 & 101.3 & 17.05 \\
\hline $2^{\prime}$ & 1.30 & 333 & 101.3 & 17.05 \\
\hline $3^{\prime}$ & 0.88 & 353 & 101.3 & 15.41 \\
\hline $4^{\prime}$ & 0.88 & 313 & 101.3 & 15.41 \\
\hline $5^{\prime}$ & 1.51 & 1073 & 1931 & 15.59 \\
\hline $6^{\prime}$ & 18.42 & 803 & 107 & 9.20 \\
\hline $7^{\prime}$ & 7.77 & 803 & 107 & 3.88 \\
\hline $8^{\prime}$ & 7.92 & 803 & 107 & 4.00 \\
\hline $9^{\prime}$ & 2.73 & 803 & 107 & 1.32 \\
\hline $10^{\prime}$ & 7.77 & 552 & 101.3 & 1.55 \\
\hline $11^{\prime}$ & 7.92 & 550.5 & 101.3 & 1.6 \\
\hline $12^{\prime}$ & 0.40 & 394 & 101.3 & 4.08 \\
\hline $13^{\prime}$ & 1.26 & 298 & 101.3 & - \\
\hline $14^{\prime}$ & - & - & - & 0.28 \\
\hline $15^{\prime}$ & 16.89 & 298 & 101.3 & - \\
\hline $16^{\prime}$ & - & - & - & 6.23 \\
\hline $17^{\prime}$ & 0.03 & 298 & 101.3 & 0 \\
\hline $18^{\prime}$ & - & - & - & 0.62 \\
\hline $19^{\prime}$ & 2.73 & 480.5 & 101.3 & 0.26 \\
\hline $20^{\prime}$ & 1.03 & 373 & 101.3 & 2.33 \\
\hline
\end{tabular}

Results of the mass and energy balances of the "partial" BIG/GTCC.

of $50 \%$ wet basis and LHV of $7.32 \mathrm{MJ} \mathrm{kg}^{-1}$. Was considered a torrefaction reactor efficiency of $60 \%$ [53].

According to the results reported in Table 9, the implementation of the Case 3 will permit a net generation of $5.33 \mathrm{MW}_{\mathrm{e}}$ for the commercialization, using the surplus bagasse of the studied plant. This configuration also allows preheating the water at the boiler entrance, using the gas turbine exhaust; improving the overall efficiency of the plant. The high cool gas efficiency obtained with the use of CHOREN Carbo- $\mathrm{V}^{\circledR}$ gasification technology, and the capacity to gasify the rich tar gas, produced during the torrefaction, permit that the introduction of the torrefaction process for the biomass pretreatment, not cause a significant reduction of the plant efficiency. The introduction of HRSG and a steam turbine for electricity generation, in combine cycle with the gas turbine, could increase the generation efficiency of the plant, but an external source of energy will be required for drying and torrefaction process.

For the calculus of the electricity generation efficiency in this
The analysis shows that for the interval of cold gas efficiencies from 88 to $78 \%$, not additional sugarcane bagasse is required for the implementation of this configuration increasing approximately $2 \%$ in the electricity generation efficiency. For lower efficiency increases of sugarcane bagasse requirement and a small growth of electricity generation is observed.

Table 10

Efficiencies of generation of electricity, heat, mechanical and overall energy and total power generated when gasified the bagasse surplus volume in the plant.

\begin{tabular}{llllll}
\hline Technologies & $\eta_{g e}[\%]$ & $\eta_{\text {Qpr }}[\%]$ & $\eta_{\text {emec }}[\%]$ & $\eta_{g l}[\%]$ & $E_{t e}[\mathrm{MW}]$ \\
\hline Conventional & 12.9 & 61.9 & 2.73 & 77.53 & 19.13 \\
BIG-GTCC & 14.7 & 55.31 & 2.44 & 72.4 & 24.30 \\
\hline
\end{tabular}




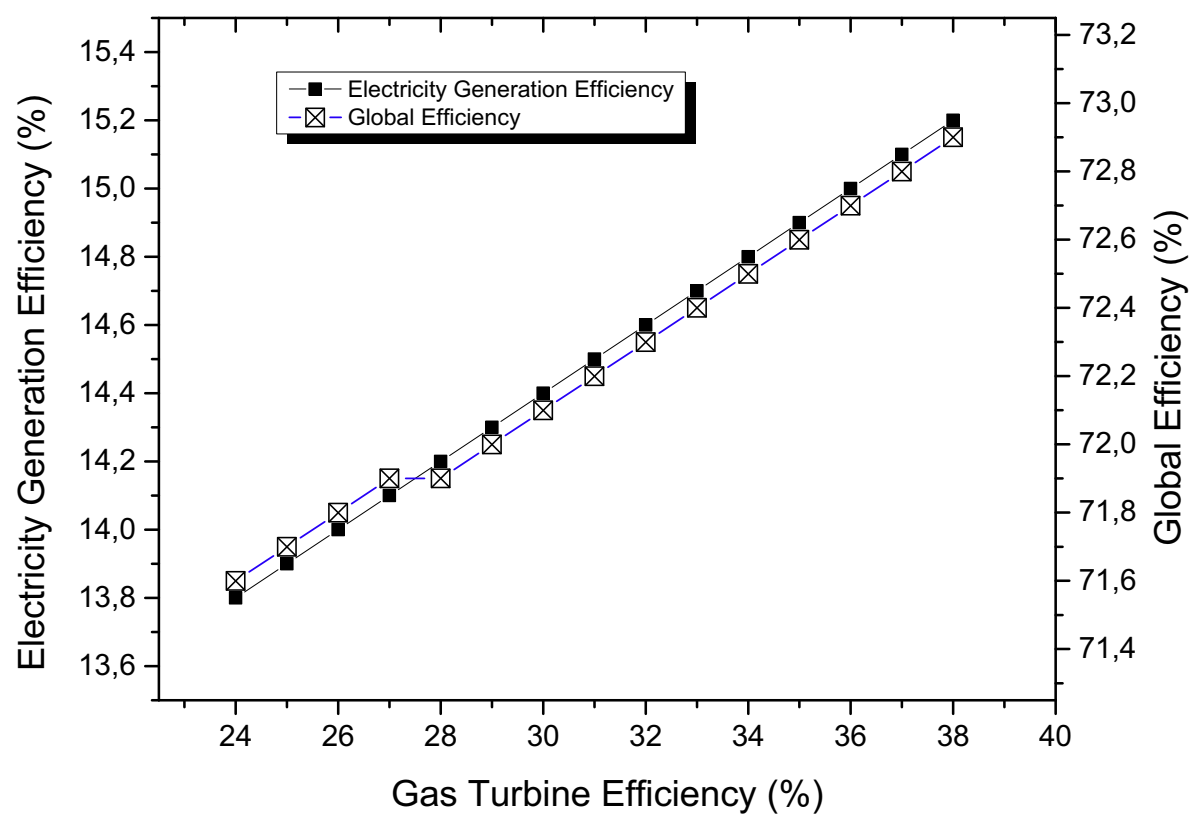

Fig. 19. Effect of variation gas turbine electricity generation efficiency on electricity and global efficiency on Case 3 .

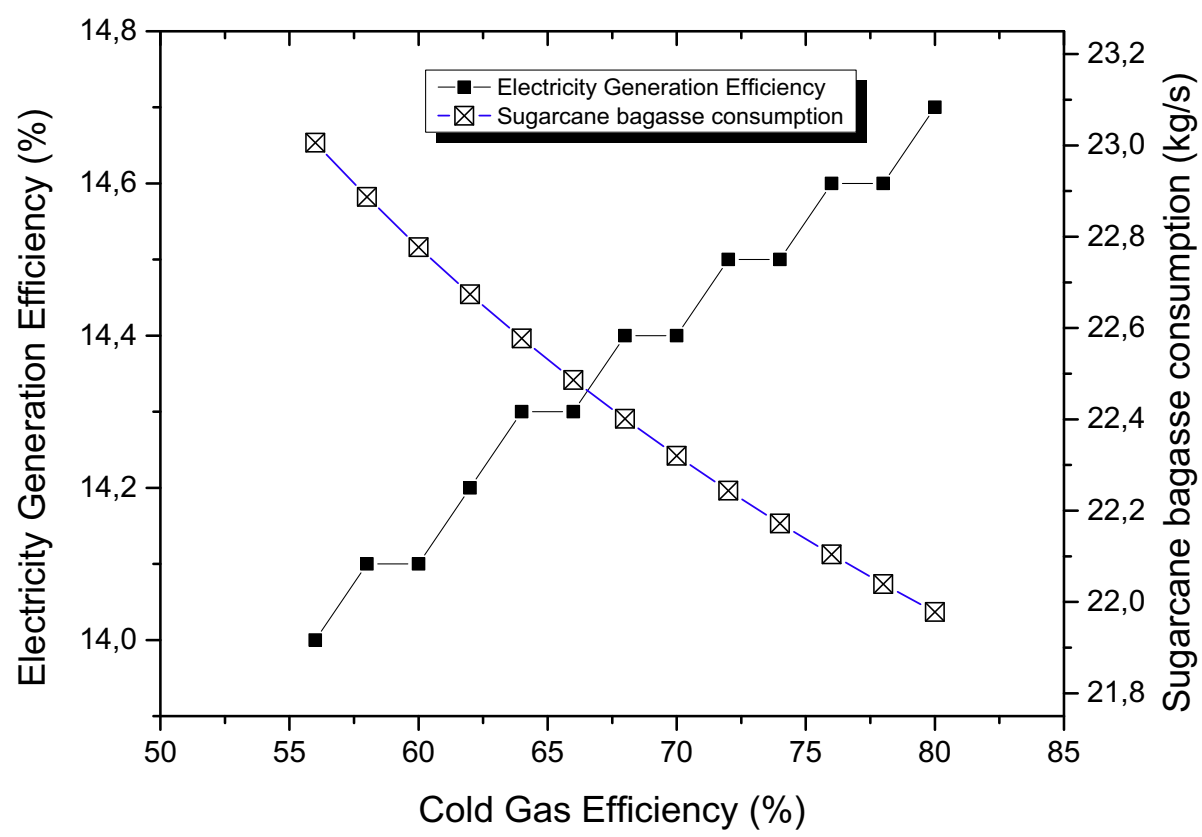

Fig. 20. Effect of variation of cold gas efficiency on electricity generation efficiency and on sugarcane bagasse consumption on Case 3 .

\section{Comparative technical analyze of three studied cases}

Fig. 21 shows a comparison of electricity generation efficiency and overall efficiency of baseline configuration with the expected after implementation of all considered configurations of the BIGGTCC technology.

In all cases, an increment in the power generation efficiency is observed after the implementation of gasification process compared to the conventional cycle. The implementation of BIGGTCC "pure" with and without torrefaction shows a significant increases.

The implementation of the "partial" BIG-GTCC, gasifying the surplus bagasse of the plant, appears as a more attractive alternative. The combination of the torrefaction pre-treatment process and the entrained flow gasifier type CHOREN Carbo- $\mathrm{V}^{\circledR}$ technology allows an electrical generation efficiency of up to $14.7 \%$, without decreasing the overall efficiency when compared with the conventional cycle. An improve on the gas turbine performance, can increase the electrical generation efficiency of this configuration up to $15.2 \%$.

\section{Conclusions}

An assessment of three probable scenario for the integration of BIG/GTCC to the studied sugar mill was conducted. In Case 1, the bagasse is gasified, rather than being burnt as in the conventional 


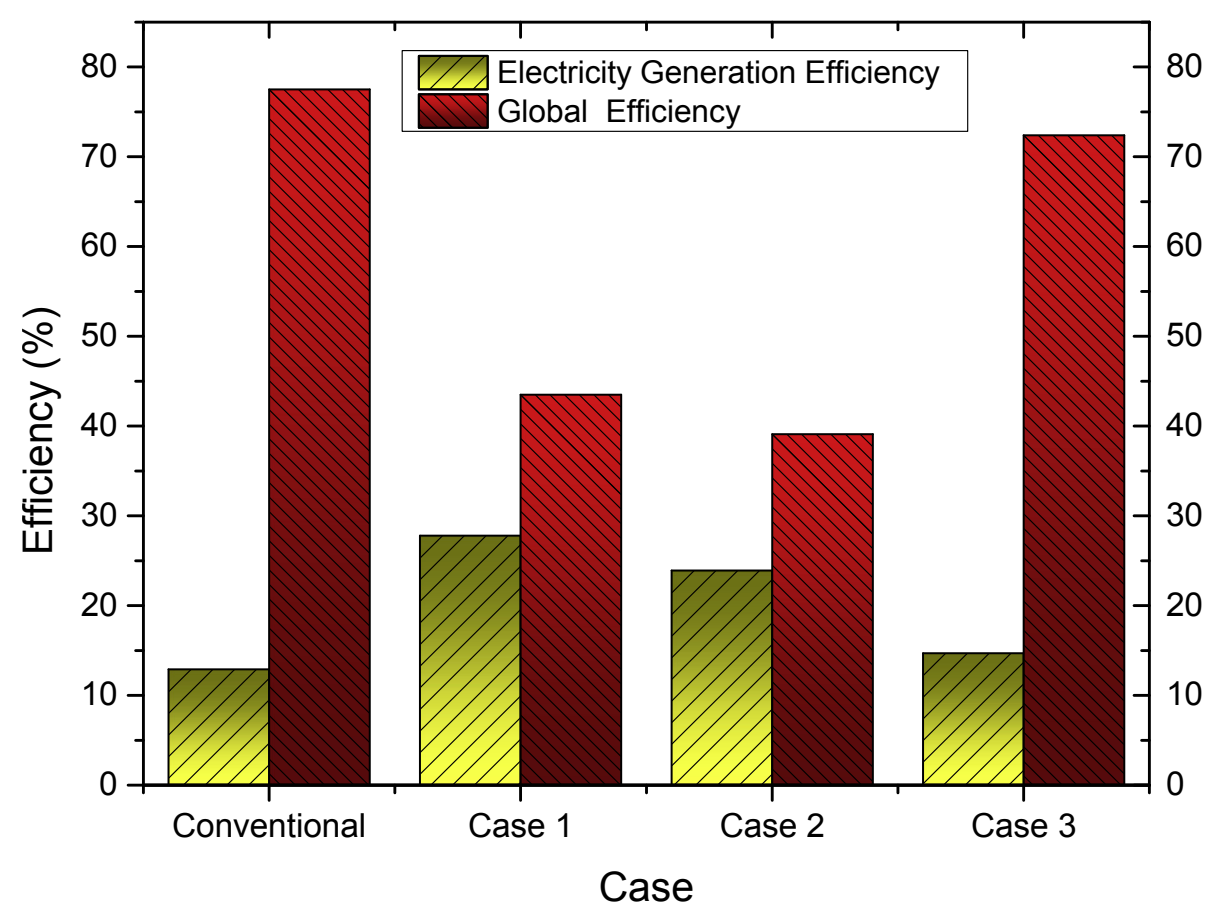

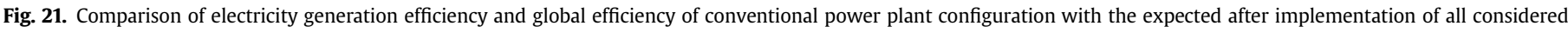
configurations of the BIG-GTCC technology.

cycle, replacing the conventional boiler by gasifier - gas turbine and HRSG assembly; were analyzed two possible configurations according to the technologies available in the market. In Case 2, was considered the possibility of gasification the bagasse in the plant in entrained flow gasifier and the replacement of conventional boiler by BIG-GTCC system, with the introduction of torrefaction as pretreatment process of sugarcane bagasse. In Case 3, was considered the gasification of surplus bagasse in entrained flow gasifier after the torrefaction as pre-treatment process. The results indicates that for sugar plants, with large steam requirements, the implementation of the "pure" BIG/GTCC, (Case 1 and 2) is not convenient due to the size of the required gas turbine and consequently the dimensions of the needed gasification island.

The implementation of the "partial" BIG/GTCC appear to be better alternative. The combination of the torrefaction pretreatment and entrained flow gasifier, CHOREN Carbo- $\mathrm{V}^{\mathbb{B}}$ type, could permit an electric generation efficiency of $14.7 \%$ and the increment of the CEST cogeneration efficiency, using wet sugarcane bagasse as feedstock. An economic study must be performed to analyze the viability of the implementation of the proposed configuration in the Case 2 and 3.

\section{Acknowledgments}

Financial support of this research is acknowledged to $\mathrm{CNPq}$ (Brazilian Council for Scientific and Technological Development) through projects $165937 / 2015-7$ and 403366/2015-1.

\section{References}

[1] P. Filippis, C. Borgianni, M. Paolucci, F. Pochetti, Gasification process of Cuban bagasse in two-stage reactor, Biomass Bioenergy 27 (2008) 247-252.

[2] E.D. Larson, R.H. Williams, M. Regis, L.V. Leal, A review of biomass integrated gasifier/gas turbine combined cycle technology and its application in sugarcane industries with an analysis for Cuba, Energy Sustain. Dev. 5 (1) (2001) $54-76$.

[3] A.V. Bridgwater, Review of fast pyrolysis of biomass and product upgrading, Biomass Bioenergy 38 (2012) 68-94.
[4] J. Kuntal, D. Sudipta, Biomass integrated gasification combined cogeneration with or without $\mathrm{CO}_{2}$ capture - a comparative thermodynamic study, Renew. Energy 72 (2014) 243-252.

[5] S.P. Babu, Thermal gasification of biomass technology developments: End of task report for 1992 to 1994, Biomass Bioenergy 9 (1-5) (1995) 271-285.

[6] A. Brito, P. Beaton, C. Ballester, C. Dopazo, Novel approach for the analysis of heat transfer in bagasse-fired furnaces, in: R.P. Overend, E. Chornet (Eds.) Proceedings of the Fourth Biomass Conference of the Americas, Oakland, August 29-September 2, Elsevier Science Ltd., Uk, 1999.

[7] J. Barroso, F. Barreras, H. Amaveda, A. Lozano, On the optimisation of boiler efficiency using bagasse as fuel, Fuel 82 (2003p) 1451-1463.

[8] T.B. Reed, A. Das, Handbook of Biomass Downdraft Gasifier Engine Systems The Biomass Energy Foundation Press, 1998.

[9] D.J. Stevens, Pacific Northwest National Laboratory, Hot Gas Conditioning: Recent Progress with Larger-scale Biomass Gasification Systems, National Renewable Energy Laboratory, 2001. Publication NREL/SR-510-29952.

[10] Einara Blanco Machin, Daniel Travieso Pedroso, Nestor Proenza, José Luz Silveira, Leonetto Conti, Lúcia Bollini Braga, Adrian Blanco Machin, Tar reduction in downdraft biomass gasifier using a primary method, Renew. Energy 78 (June 2015) 478-483.

[11] D.T. Pedroso, E.B. Machin, J.L. Silveira, Y. Nemoto, Experimental study of bottom feed updraft gasifier, Renew. Energy (2013) 311-316.

[12] T. Murakami, G. Xu, T. Suda, Y. Matsuzawa, H. Tani, T. Fujimori, Some process fundamentals of biomass gasification in dual fluidized bed, Fuel 86 (2007) 244-255.

[13] N. Proenza Pérez, E.B. Machin, D.T. Pedroso, J.S. Antunes, J.L. Silveira, Fluiddynamic assessment of sugarcane bagasse to use as feedstock in bubbling fluidized bed gasifiers, Appl. Therm. Eng. 73 (1) (2014) 238-244.

[14] T.N. Jiqing Fan, M.A. Kalnes, K. Jordan, D.R. Sadehvandi, Shonnard, Life cycle assessment of electricity generation using fast pyrolysis bio-oil, Renew. Energy 36 (2) (2011) 632-641.

15] G.A. Dantas, L.F.L. Legey, A. Mazzone, Energy from sugarcane bagasse in Brazil: an assessment of the productivity and cost of different technological routes Renew. Sustain. Energy Rev. 21 (2013) 356-364.

[16] A.V. Bridgwater, A.J. Toft, J.G. Brammer, A techno-economic comparison of power production by biomass fast pyrolysis with gasification and combustion, Renew. Sustain. Energy Rev. 6 (3) (2002) 181-246.

[17] J. Bourgeois, R. Guyonnet, Characterization and analysis of torrefied wood, Wood Sci. Tech 22 (1988) 143-155.

[18] P. Rein, Cane Sugar Engineering, Verlag Dr. Albert Bartens KG, Berlim, 2007 p. 768.

[19] C.A. Camargo, H.A. Ushima, Conservation of Energy in the Sugar and Alcohol Industry, Institute of Technological Research - Ipt, (in Portuguese) São Paulo, 1992, p. 796.

[20] B.M. Jenkins, L.L. Baxter, T.R. Miles Jr., T.R. Miles, Combustion properties of biomass, Fuel Process. Technol. 54 (1998) 17-46.

[21] IPT, Tutorials of the Industrial Combustion Course (In Portuguese), 2007. São 
Paulo.

[22] P. Filippis, C. Borgianni, M. Paolucci, F. Pochetti, Gasification process of Cuban bagasse in two-stage reactor, Biomass Bioenergy 27 (2008) 247-252.

[23] G.M. Pérez, A. Chaala, C. Roy, Co-pyrolysis of sugarcane bagasse with petro leum residue. Part Ii. Product yields and properties, Fuel 81 (2002) 893-907.

[24] T.R. Miles, T.R. Miles Jr., L. Baxter, R.W. Bryers, B.M. Jenkins, L.L. Oden, Alkal deposits found in biomass power plants. A preliminary investigation of their extend and nature, NREL/TP 433 (1995) 8142-8182.

[25] F. A.Agblevor, H. L. Chum, D. K. Johnson, Compositional Analysis of Nis Biomass Standards from the Iea Whole Feedstock Round Robin. Energy from Biomass and Wastes Xvi: Proceedings of the Institute of Gas Technology Conference, 2-6 March 1992, Orlando, Florida. Chicago, Il: Institute of Gas Technology; pp. 395-421.

[26] E. Natarajan, M. Ohman, M. Gabra, A. Nordin, T. Liliedahl, A.N. Rao, Experimental determination of bed agglomeration tendencies of some common agricultural residues in fluidized bed combustion and gasification, Biomass Bioenergy 15 (1998) 163-169.

[27] M.J. Prins, K.J. Ptasinski, F.J.J.G. Janseen, Thermodynamics of gas-char reactions: first and second law analysis, Chem. Eng. Sci. 58 (3-6) (2003) 1003-1011.

[28] R. Karamarkovic, V. Karamarkovic, Energy and exergy analysis of biomass gasification at different temperatures, Energy 35 (2) (2010) 537-549.

[29] Nor Hakimin Abdullah, Wan Azelee Wan Abu Bakar, Rafaqat Hussain, Mohd Bakri Bakar, Mazlan Mohamed, Mohammad Khairul Azhar Abdul Razab, Jan H. Van Esch, Preparation and characterization of alkyl-thiols monolayer on glass substrates by microcontact printing, J. Eng. Appl. Sci. 10 (20) (November, 2015).

[30] Hakan Karatas, Hayati Olgun, Berrin Engin, Fehmi Akgun, Experimental results of gasification of waste tire with air in a bubbling fluidized bed gasifier, Fuel 105 (March 2013) 566-571.

[31] Hakan Karatas, Hayati Olgun, Fehmi Akgun, Experimental results of gasification of waste tire with air\&CO2, air\&steam and steam in a bubbling fluidized bed gasifier, Fuel Process. Technol. 102 (October 2012) 166-174.

[32] D.Y.C. Leung, C.L. Wang, Fluidized-bed gasification of waste tire powders, Fue Process. Technol. 84 (1-3) (15 November 2003) 175-196.

[33] J.S. Antunes, Computer Code for Analysis of Cogeneration Systems with Gas Turbines, Guaratinguetá, São Paulo State University, Faculty of Engineering of Guaratinguetá, 1999, p. 157. PhD Thesis. (in portuguese).

[34] Gas Turbine World, Gtw Handbook, in: Project Planning, Pricing, Engineering, Construction and Operation, vol. 29, 2012. Pequot.

[35] A. Pantalena, Cogeneration for Small and Medium Milk Products Industries, Dissertation, São Paulo State University, Faculty of Engineering of Guaratinguetá, 1997 (in portuguese).

[36] F. J Brooks. Ge gas turbine performance characteristics. Ge Power Systems, Schenectady, Ny. General Electric Reference Document - GER-3567H.
Consulted in 2014

[37] R. Treloar, Gas installation Technology, John Wiley \& Sons, 2010.

[38] R. Kurz, Gas turbine performance, in: Proceedings of the Thirty-fourth Turbomachinery Symposium. College Station, Texas, Usa, 2005.

[39] E4TECH, Review of Technology for the Gasification of Biomass and Wastes, 2009. http://www.ecolateral.org/gasificationnnfc090609.pdf. Available from:

[40] M. Worley, J. Yale, Biomass Gasification Technology Assessment, Consolidated Report 2012, National Renewable Energy Laboratory (NREL)-SR-5100-57085, 2012.

[41] Sustainable Energy Systems, Report on Energy Efficient and Renewable Energy Systems Planning and Recommendations for Their Successful Application, POLYCITY - DR 1.1 TREN/05FP6EN/S07.43964/513481, 2006.

[42] Paul Henderick, An Assessment of Biomass-powered Microturbines and the Potential for Application in Rural China, PU/CEES Report No. 322, Center for Energy and Environmental Studies, Princeton University, 2000.

[43] Thyssen Krupp Company, Gasification Technologies, GT 620e/2000 8/2011 GZD/TK, 2011.

[44] Greet, The Greenhouse Gases, Regulated Emissions, and Energy Use in Transportation Model, 1.8d.1, Argonne National Laboratory, Argonne, Il, 2010.

[45] K.E Starling, J.L. Savidge, Compressibility Factors for Natural Gas and Other Related Hydrocarbon Gases, American Gas Association (AGA) Transmission Measurement Committee Report No. 8, American Petroleum Institute (API) Mpms, Chapter 14.2, second ed., 1992. November 1992.

[46] P.J. van den Enden, E. Silva Lora, Design approach for a biomass fed fluidized bed gasifier using the simulation software Csfb, Biomass Bioenergy 26 (3) (2004) 281-287.

[47] L.F. Pellegrini, S. Oliveira Junior, Exergy analysis of sugarcane bagasse gasification, Energy 32 (4) (2007) 314-327.

[48] G.E. Olivares, B.L.A. Cortez, S.E. Lora, G.C. Sanchez, A. Bauen, Preliminary tests with a sugarcane bagasse fueled fluidized-bed air gasifier, Energy Convers. Manag. 40 (2) (1999) 205-214.

[49] S. Babu, Biomass Gasification for Hydrogen Production - Process Description and Research Needs, Technology Report from Task 33, International Energy Agency, 2010.

[50] P. Basu, Combustion and Gasification in Fluidized Beds, Taylor \& Francis, 2006, pp. 355-357.

[51] A. Pimchuai, A. Dutta, P. Basu, Torrefaction of agriculture residue to enhance combustible properties, Energy Fuels 24 (2010) 4638-4645.

[52] T. Blades, M. Rudloff, O. Schulze, Sustainable SunFuel from CHOREN's Carbo$V ®$ process, in: Presented at International Symposia on Alcohol Fuels -Isaf Xv, San Diego, 2005.

[53] A. Shah, J.D. Matthew, M. Dorde, P.A. Robert, S. Khanal, D. Maski, Technoeconomic analysis of a production-scale torrefaction system for cellulosic biomass upgrading, Biofuels, Bioprod. Biorefining 6 (1) (January/February 2012) 45-57. 